\title{
In silico and in vitro Evaluation of Mimetic Peptides as Potential Antigen Candidates for Prophylaxis of Leishmaniosis
}

Deborah Carbonera Guedes ${ }^{1+}$, Manuel Hospinal Santiani ${ }^{1+}$, Joyce Carvalho ${ }^{1}$,

OPEN ACCESS

Edited by:

Simone Brogi,

University of Pisa, Italy

Reviewed by:

Maria Agallou,

Pasteur Hellenic Institute, Greece

Mauro Magnani,

University of Urbino Carlo Bo, Italy

Iraj Sharifi,

Kerman University of Medical

Sciences, Iran

*Correspondence:

Vanete Thomaz-Soccol

vanetesoccol@gmail.com

tThese authors have contributed equally to this work

Specialty section: This article was submitted to Medicinal and Pharmaceutical Chemistry,

a section of the journal Frontiers in Chemistry

Received: 31 August 2020 Accepted: 08 December 2020 Published: 15 January 2021

Citation:

Guedes DC, Santiani MH, Carvalho J, Soccol CR, Minozzo JC, Machado de Ávila RA, de Moura JF, Ramos ELP, Castro GR, Chávez-Olórtegi $C$ and Thomaz-Soccol V (2021) In silico and in vitro Evaluation of Mimetic Peptides as Potential Antigen Candidates for Prophylaxis of Leishmaniosis. Front. Chem. 8:601409.

doi: 10.3389/fchem.2020.601409
Carlos Ricardo Soccol ${ }^{1}$, João Carlos Minozzo ${ }^{1,2}$, Ricardo Andrez Machado de Ávila ${ }^{3}$, Juliana Ferreira de Moura ${ }^{1}$, Eliezer Lucas Pires Ramos ${ }^{1}$, Guillermo Raul Castro ${ }^{4,5}$, Carlos Chávez-Olórtegi ${ }^{6}$ and Vanete Thomaz-Soccol ${ }^{1 *}$

\begin{abstract}
1 Programa de Pós-Graduação Strictu Sensu em Engenharia de Bioprocessos e Biotecnologia, Universidade Federal do Paraná, Curitiba, Brazil, ${ }^{2}$ Centro de Produção e Pesquisa de Imunobilógicos, Secretaria De Saúde do Estado do Paraná, Piraquara, Brazil, ${ }^{3}$ Programa de Pós Graduação em Ciência da Saúde, Universidade do Extremo Sul Catarinense, Criciúma, Brazil, ${ }^{4}$ Laboratorio de Nanobiomateriales, CINDEFI, Departamento de Química, Facultad de Ciencias Exactas, Universidad Nacional de La Plata (UNLP)-CONICET (CCT La Plata), La Plata, Argentina, ${ }^{5}$ Max Planck Laboratory for Structural Biology, Chemistry and Molecular Biophysics of Rosario (MPLbioR, UNR-MPIbpC), Partner Laboratory of the Max Planck Institute for Biophysical Chemistry (MPIbpC, MPG), Centro de Estudios Interdisciplinarios (CEI), Universidad Nacional de Rosario, Rosario, Argentina, ${ }^{6}$ Departamento de Bioquímica e Imunologia, Instituto de Ciência Biológicas, Universidade Federal de Minas Gerais, Belo Horizonte, Brazil
\end{abstract}

Antigen formulation is the main feature for the success of leishmaniosis diagnosis and vaccination, since the disease is caused by different parasite species that display particularities which determine their pathogenicity and virulence. It is desirable that the antigens are recognized by different antibodies and are immunogenic for almost all Leishmania species. To overcome this problem, we selected six potentially immunogenic peptides derived from Leishmania histones and parasite membrane molecules obtained by phage display or spot synthesis and entrapped in liposome structures. We used these peptides to immunize New Zealand rabbits and determine the immunogenic capacity of the chimeric antigen. The peptides induced the production of antibodies as a humoral immune response against $L$. braziliensis or $L$. infantum. Next, to evaluate the innate response to induce cellular activation, macrophages from the peptide mix-immunized rabbits were infected in vitro with $L$. braziliensis or $L$. infantum. The peptide mix generated the IFN- $\gamma, \mathrm{IL}-12, \mathrm{IL}-4$ and TGF- $\beta$ that led to Th1 and Th2 cellular immune responses. Interestingly, this mix of peptides also induced high expression of iNOS. These results suggest that the mix of peptides derived from histone and parasites membrane molecules was able to mimic parasites proteins and induce cytokines important to CD4+ T cell Th1 and Th2 differentiation and effector molecule to control the parasite infection. Finally, this peptide induced an immune balance that is important to prevent immunopathological disorders, inflammatory reactions, and control the parasite infection.

Keywords: mimetic peptides, cytokines, in vitro infection, vaccines, leishmaniasis 


\section{INTRODUCTION}

Despite all the advances in the field of immunization and different strategies to identify new antigenic molecules, there is still no antigen capable of inducing Leishmania spp. control and protecting individuals against leishmaniosis. Moreover, the large number of Leishmania species, responsible for cutaneous and visceral forms, and the differences among them make the diagnosis of these pathologies harder (Maroof et al., 2012). Thus, it is essential to search for new technologies to develop antigen candidates for diagnosis or a vaccine to induce the control of these diseases in individuals who reside in at risk regions (De Brito et al., 2018).

Given this scenario, an attractive alternative is peptidebased antigens that use epitopes of immunogenic proteins, which can stimulate a long-lasting immune response against the pathogen. This approach is a promising strategy, since it could even promote protection against Leishmania, it is a potent therapeutic tool to treat the disease (Skwarczynski and Toth, 2016; De Brito et al., 2018), could be applied in diagnosis (Link et al., 2017), and used to develop antigens to stimulate cellular immunity for potential use in vaccine protocols (Hamrouni et al., 2020). Furthermore, peptides are easier to produce and show greater stability. These antigens are produced by chemical synthesis, reducing problems with biological contamination. Antigens can be characterized as chemical molecules, similar to classical drugs, their production is reproducible, simple, costeffective and fast, and low cost to scale-up (Joshi et al., 2014). Concerning immunity, these antigens can be customizing to generate specific responses and can be combined to design multiepitopes or multi-specific antigens to target different Leishmania species or immunogenic molecules from different stages of the parasite life cycle. Despite all the advantages, this approach has some challenges, such as enhancing the immunogenicity of the peptides. One of the strategies to overcome this challenge is to design a multi-epitope-based antigen, which consists of incorporating multiple epitopes that allows for better coverage of natural pathogen antigen diversity (Moyle and Toth, 2013; De Brito et al., 2018).

The effectivity of a vaccine to promote a long-lasting cell mediated immune response also depends on the molecules used as antigens in the different production approaches. A high diversity of virulent Leishmania molecules have been tested as antigens, including gp63 (glycoprotein leishmaniolysin), SLA (soluble Leishmania antigen), LPG (lipophosphoglycan), histones, and several other purified antigens (Khamesipour et al., 2006; Olivier et al., 2012; Chamakh-Ayari et al., 2014; Martínez Salazar et al., 2014; Link et al., 2017).

Among these molecules, histones are potential candidates against leishmaniosis, since they constitute structural proteins that are important in the organization and regulation of the parasite genes. There are four major Leishmania histone classes $-\mathrm{H} 2 \mathrm{~A}, \mathrm{H} 2 \mathrm{~B}, \mathrm{H} 3$, and $\mathrm{H} 4-$ that are basic component units of chromatin, the nucleosome (Requena et al., 2000). These molecules are highly conserved antigens, produced by several Leishmania species, which are non-secreted, but are able to induce an intense immune response (Santarem et al., 2007).
These proteins are released during the infection process after the elimination of intracellular amastigotes by active macrophages. Moreover, they can modulate the host immune response, since they do not suffer selective pressure by the host immunity, unlike surface secreted proteins of Leishmania (Chang et al., 2003).

The identification and selection of an epitope are crucial stages to develop a peptide-based antigen. It is necessary to map the whole protein of interest to identify suitable sequences that can induce a strong and permanent cellular immunity response against Leishmania parasites. These epitopes can be identified in silico and analyzed by bioinformatics tools that focus on $\mathrm{T}$ and $\mathrm{B}$ cell epitopes prediction, identification of conserved Leishmania species sequences, and location of the sequence on the protein quaternary conformation (Herrera-Najera et al., 2009; Freitas et al., 2016). The second approach is in vitro analysis of the epitopes by biotechnological and biochemical tools, such as phage display and spot synthesis techniques (Pini et al., 2005; Rhaiem and Houimel, 2016).

Our research group has been working in these areas to improve and develop diagnosis and prophylaxis techniques for the different neglected tropical diseases (NTDs). Some of these previous works have shown great promise regarding the evaluation of mimetic peptides as antigens for leishmaniosis diagnosis and vaccines (Seger, 2014; Link et al., 2017; Guedes et al., 2019). Based on previously obtained results with three mimetic peptides selected by phage display and chemically synthesized as soluble molecules, their potential as antigens was evaluated in skin tests. The peptides, individually (PA1, PA2, and PA3) or in a mix (PA1,2,3-Mix), were tested on an animal model (Cavia porcellus) immunized with dead L. amazonensis or L. braziliensis and compared with the standard skin test antigen. The results showed that the peptides, individually or in a mix, promoted induration reactions 48 and $72 \mathrm{~h}$ after inoculation (Guedes et al., 2019). These results indicate that these peptides can recruit and maintain a desired immune response and that they can be applied as antigens for immune prophylaxis purposes. Based on these findings, this work proposed the investigation of new active peptides derived from histone proteins of Leishmania spp. though the production of a chimeric molecule with the three peptides previously selected by our group. The biological activity of this chimeric molecule was investigated to verify its potential to activate a satisfactory immune response for diagnosis or as a candidate vaccine.

\section{MATERIALS AND METHODS}

The method used in this work consists of two main steps illustrated in Figures 1, 2. The first involved the selection, synthesis, and evaluation of peptides. The second included experimental procedures to evaluate the immunogenicity of these peptides by analyzing humoral and macrophages immune responses. Regarding the first step, seven intracellular immunogenic proteins from Leishmania spp. (histone classes $\mathrm{H} 2 \mathrm{~A}, \mathrm{H} 2 \mathrm{~B}, \mathrm{H} 3$ and $\mathrm{H} 4$, and $\mathrm{HP} 1$ ) were selected and spot synthesized, followed by the selection of reactive peptides by immunodetection assay (Figure 1, step 1). The reactive spots 


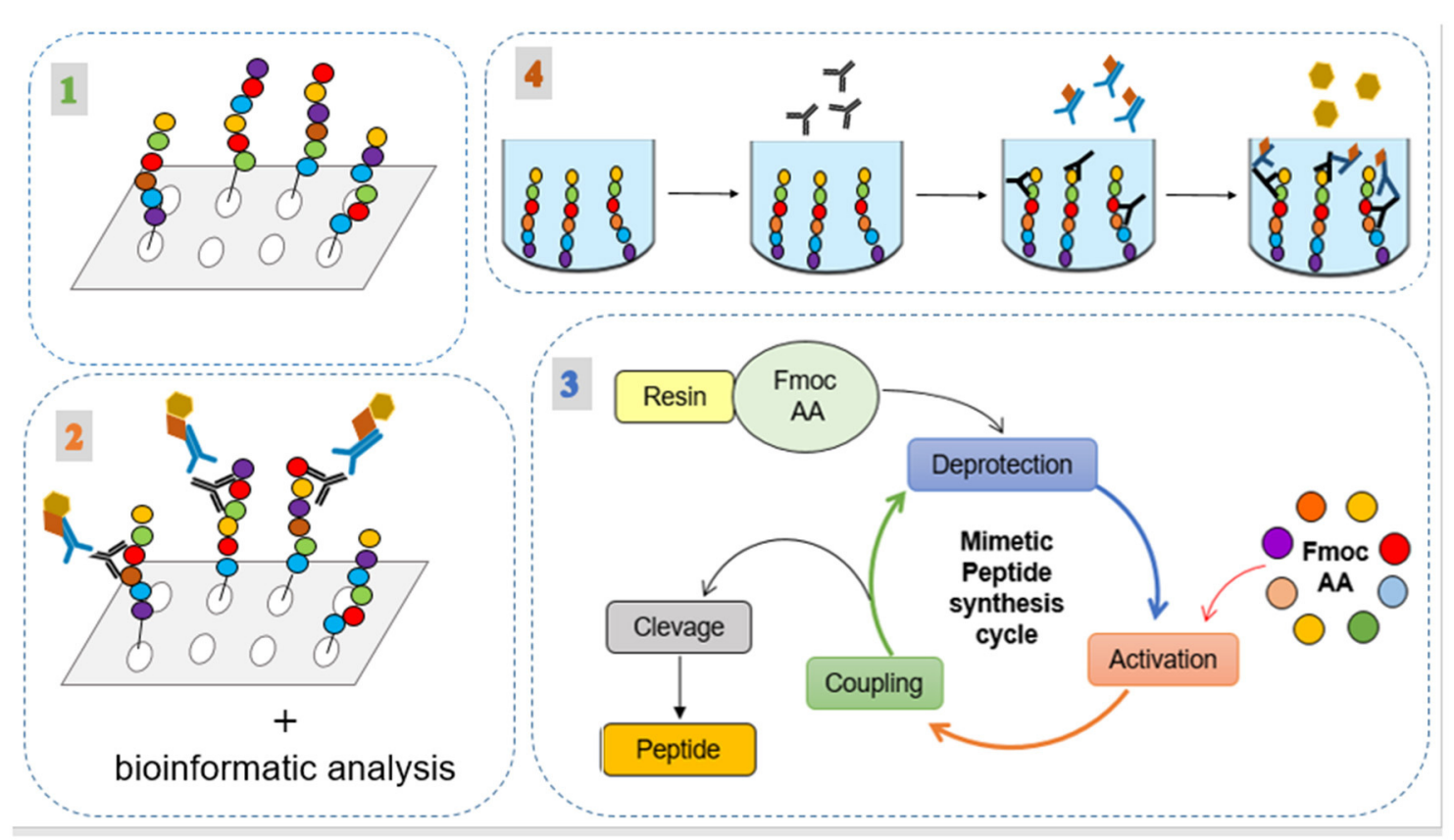

FIGURE 1 | Experimental processes for the selection, synthesis, and evaluation of the peptides. (1) Spot synthesis of the intracellular immunogenic proteins from Leishmania spp.; (2) Immunodetection assay of reactive spots; (3) their analysis by bioinformatic tools; and (4) application of the peptides in indirect ELISA method using human serum.

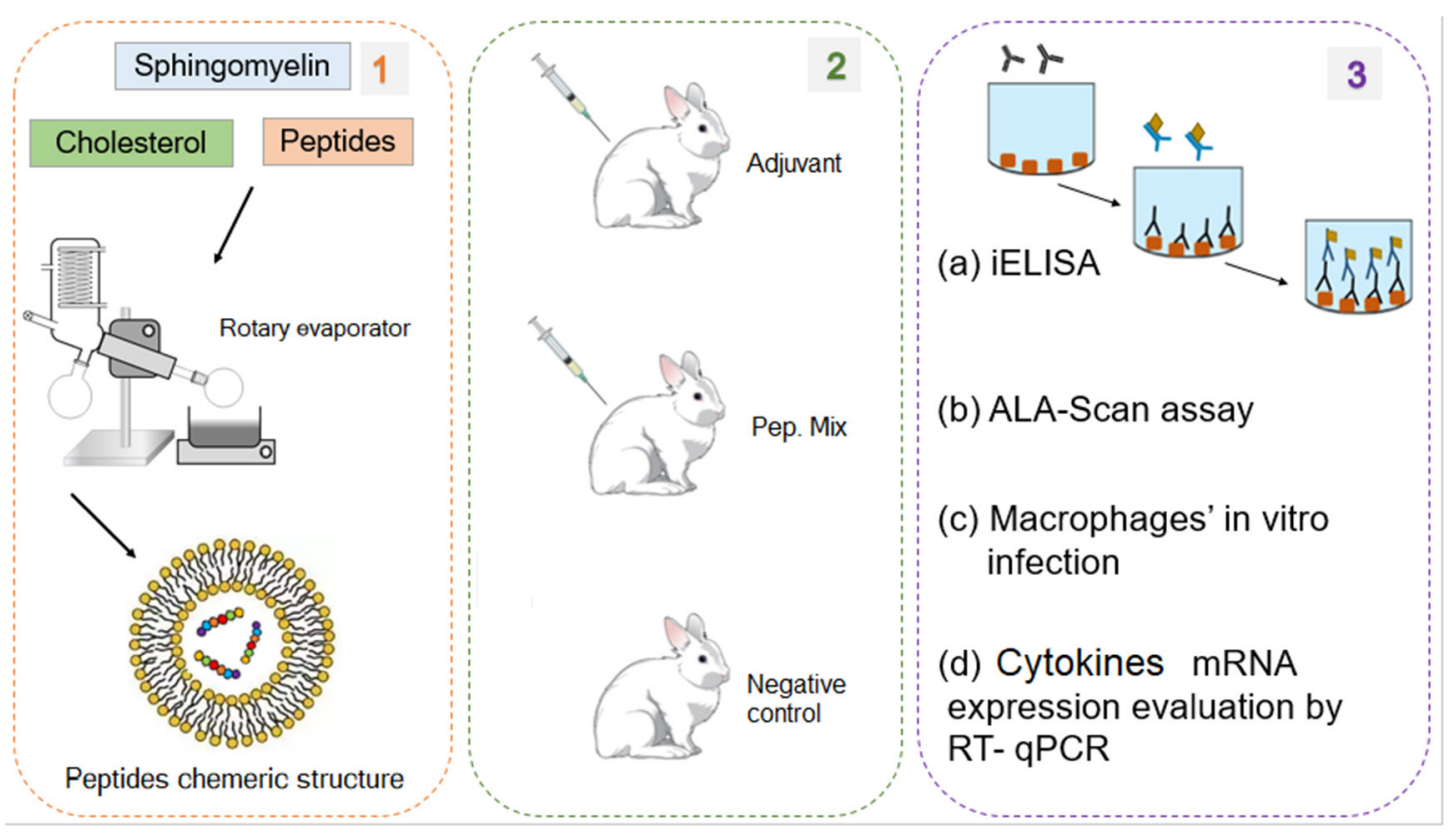

FIGURE 2 | Experimental processes for the production and evaluation of the peptide chimeric molecules. (1) Peptides encapsulation in liposomes. (2) Rabbits immunization with mix of six peptides (chimeric molecule) to produce anti-peptide polyclonal antibodies. (3) Evaluation of the peptides immunogenic capacity to induce immune response: (a) ELISA assay to evaluate lgG antibody production profile; (b) Evaluation of ALA scanning peptides with rabbit anti-peptide polyclonal antibodies; (c) in vitro experimental infection of macrophages from rabbits immunized with peptides; (d) Evaluation of cytokines mRNA expression profile by RT-qPCR.

were analyzed by bioinformatics tools to evaluate their chemical and structural characteristics to verify protein regions that manifest epitope-like features (Figure 1, step 2). The selected peptides were chemically synthesized (Figure 1, step 3) and encapsulated in liposome structures (Figure 2, step 1), with the other three previously selected peptides, to formulate 
the peptide-based antigen (see section Results). In sequence, the peptide-based antigen was used to immunize a group of New Zealand rabbits (Figure 2, step 2) and in vitro analyses were performed to evaluate the capacity of the peptide-based antigen to stimulate humoral and macrophage responses against L. braziliensis or for L. infantum (Figure 2, step 3). Other analyses were performed to verify the peptide characteristics that contributed to their selection (Figure 2, step 3).

All applicable international, national, and institutional guidelines for the care and use of animals were followed. The study was approved by the Research Ethics Committee of the Federal University of Parana (process no. 23075.085350/2015-54 and 107/11).

\section{Peptide Selection}

The proteins selected for this study were immunogenic intracellular molecules derived from $L$. amazonensis and $L$. braziliensis histones. The sequences of histones were accessed on the UniProt database and identified as HP1 (UniProt accession number: Q9NL78), HP2 (Q9NL77), HP3 (Q9BMY8), HP4 (A4H9W0), HP5 (A4HBV1), HP6 (O44009), and HP7 (A4HNK4). The homology of the protein sequences among Leishmania sp. (L. amazonensis, L braziliensis and L. infantum) were verified by EMBOSS Needle pairwise sequence alignment (Rice et al., 2000).

The seven selected protein sequences were spot synthesized by overlapping pentadecapeptides, with an offset of three amino acids, scanning aimed at selecting and evaluating the reactivity of epitopes on these sequences. The spot synthesis was performed on a cellulose membrane with fluorenylmethyloxycarbonyl (Fmoc) protection using an automated spot peptide synthesizer (Intavis Bioanalytical Instruments, Nattermannallee, Germany) (Frank, 2002). For the immunodetection assay to select and evaluate the reactive spots, the cellulose membrane was firstly blocked, for non-specific binding, by overnight agitation with $3 \%$ $(\mathrm{w} / \mathrm{v})$ casein and $0.5 \%(\mathrm{w} / \mathrm{v})$ sucrose dissolved in TBS-T $(0.1 \%$ Tween $20(\mathrm{v} / \mathrm{v})$ in TBS) at $4^{\circ} \mathrm{C}$. Afterwards, the membrane was washed with $0.1 \%$ TBS-T for 10 min under agitation, and probed, for $90 \mathrm{~min}$ at $37^{\circ} \mathrm{C}$, with patients serum containing antibodies for L. braziliensis or L. infantum, or negative control diluted 1:100 in blocking buffer $(3 \%(\mathrm{w} / \mathrm{v})$ casein, $0.5 \%(\mathrm{w} / \mathrm{v})$ sucrose, and $0.1 \%$ TBS-T). The membrane was washed again and incubated with biotin-labeled secondary antibody $(1: 30,000)$ diluted in blocking buffer for $60 \mathrm{~min}$ at $37^{\circ} \mathrm{C}$, followed by an incubation step with streptavidin $(1: 10,000)$ diluted in blocking buffer for $60 \mathrm{~min}$ at $37^{\circ} \mathrm{C}$. After two washes, positive spots were visualized by electrochemiluminescence (ECL ${ }^{\mathrm{TM}}$ system).

To complement the selection of reactive peptides, the protein sequences were analyzed using bioinformatics tools such as Peptide 2.0 (https://www.peptide2.com/main_about.php), IPC (Kozlowski, 2016) and PepCalc (https://pepcalc.com/) to evaluate characteristics like molecular weight, isoelectric point, net charge, and hydrophobicity. Other tools, such as Epitopia server (Rubinstein et al., 2009), ABCpred (Saha and Raghava, 2006), and IEDB Analysis Resource (Vita et al., 2015), were used to verify protein regions that manifest epitope-like characteristics. Additionally, the $3 \mathrm{D}$ structure of proteins was obtained by a homology-modeling server, SwissModel (Guex and Peitsch, 1997), using the histones X-ray diffraction structure as templates and the predicted epitopes were analyzed by Swiss-Pdb Viewer (Guex and Peitsch, 1997). Analyses of the 3D structures of the proteins were performed to evaluate where the reactive peptides (their sequences) were located on the protein structure, which contributed to verifying whether they are more exposed or internal. Finally, the peptide sequences were BLASTed against Leishmania spp. protein sequences, using TriTrypDB to analyze the similarities between them (Aslett et al., 2010).

\section{Chemical Synthesis of Selected Peptides}

The peptides selected by immunodetection assay and analyzed by bioinformatics tools were chemically synthesized according standard protocol by Fmoc strategy (9fluorenylmethyloxycarbonyl) using a resin as insoluble solid support (Merrifield, 1969) with a MultiPep RS automated peptide synthesizer (Intavis Bioanalytical Instruments, Nattermannallee, Germany). After the final synthesis cycle, the peptides were released from the resin by trifluoracetic acid treatment, filtered and precipitated with cold ethyl ether, yielding the peptides. After centrifugation, the ether was discarded and peptides were lyophilized, weighed, dissolved in ultrapure water, and stored at $-20^{\circ} \mathrm{C}$ until the next step.

To reduce the number of peptides selected by the bioinformatics tools after chemical synthesis, they were tested by indirect ELISA (iELISA) for humoral response using serum from human patients with anti-L. braziliensis or anti- $L$. infantum antibodies. The aim was to determine whether the peptides induce a mimicked response to the parasite.

\section{Reactive Peptides Encapsulation in Liposome}

The immunogenic peptides (selected in this work by spot synthesis) plus three peptides previously selected by our research group (selection determined by phage display and hypersensitivity reaction named P1, P2, and P3 for detail, see Link et al., 2017; Guedes et al., 2019), were encapsulated in liposome according to Toledo-Machado et al. (2015), producing the peptide-based antigen. Briefly, the encapsulated peptides were produced by dissolving sphingomyelin $(25 \mathrm{mg})$ and cholesterol $(6.5 \mathrm{mg})$ in $5 \mathrm{~mL}$ solution containing methanol and chloroform (1:2). The solvent was removed by flash evaporation on a rotatory evaporator at $37^{\circ} \mathrm{C}$ and dried for $80 \mathrm{~min}$ under reduced pressure. Next, an aqueous phase containing the six peptides $(500 \mu \mathrm{g}$ of each peptide) diluted in $3 \mathrm{~mL}$ of PBS pH 7.4 was added to lipid film composing the liposome structures with the six peptides encapsulated. To dislodge and retrieve the liposomes they were treated three times with ultrasonic vibration for $20 \mathrm{~s}$. To remove no encapsulated peptides, the liposome suspension was washed twice by centrifugation $\left(10 \mathrm{~min}, 8,000 \mathrm{~g}\right.$ at $4^{\circ} \mathrm{C}$ ) and resuspended in $\mathrm{PBS} \mathrm{pH}$ 7.4. After washing, the liposomes were lyophilized and stored at $4^{\circ} \mathrm{C}$.

\section{Polyclonal Antibody Production}

To produce polyclonal antibodies, five adult female New Zealand White rabbits (NZW), weighing 2.1-2.6 kg were used. The rabbits 
were housed in single cages in a standard animal room $\left(20^{\circ} \mathrm{C}\right.$ and 55\% humidity) and fed a balanced diet and water ad libitum. The rabbits were divided in three groups: Group 1, immunized with the adjuvant (aluminum hydroxide); Group 2, immunized with the peptides mix entrapped in liposome; and Group 3, no immunization (uninfected group). For the first immunization (day 0), Group 1 was submitted to intramuscular injection with $1 \mathrm{~mL}$ of aluminum hydroxide; Group 2 was submitted to intramuscular injection with $500 \mu \mathrm{g} / \mathrm{rabbit}$ (Melo et al., 2020) of entrapped peptides mix dissolved in PBS buffer ( $\mathrm{pH} 7.4$ ) and $1 \mathrm{~mL}$ of aluminum hydroxide (adjuvant); and Group 3 (negative control) was not immunized. The other immunizations were performed under the same conditions on days $15,30,45,60$, and 90 after the first immunization (a.f.i.). On day 90, the rabbits were bled, euthanized and macrophages were collected for the in vitro assay.

Blood samples for polyclonal antibody reactivity evaluation were obtained before every immunization (days 0, 15, 30, 45, and 60 ), by vein puncture from the marginal ear vein of the rabbits and transferred to vacutainer blood collection tubes. For cytokines evaluation, blood samples were collected at 48 and $72 \mathrm{~h}$ a.f.i. (day 0 ) and transferred to vacutainer blood collection tubes containing $200 \mu \mathrm{L}$ of TRIzol. After each sample collection, they were centrifuged at $448 \mathrm{xg}$, for $10 \mathrm{~min}$, at room temperature, resuspended in red blood cell (RBC) lysis buffer $\mathrm{pH} 7.3(89.9 \mathrm{~g}$ of $\mathrm{NH}_{4} \mathrm{Cl} ; 10 \mathrm{~g}$ of $\mathrm{KHCO}_{3} ; 2 \mathrm{~mL}$ of EDTA $0.5 \mathrm{M}$ ), incubated for $5 \mathrm{~min}$ and centrifuged for $2 \mathrm{~min}, 1,008 \mathrm{x} \mathrm{g}$ at room temperature. The supernatant was discarded, and the pellet was resuspended in PBS, centrifuged for $2 \mathrm{~min}, 1,008 \mathrm{x}$ at room temperature and resuspended in $400 \mu \mathrm{L}$ of TRIzol. The samples were stored at $-80^{\circ} \mathrm{C}$.

\section{Anti-IgG Antibody Production Profile}

An indirect ELISA assay was performed to evaluate the profile of the polyclonal antibody reactivity obtained during the rabbits' immunization period. The microtiter plates were coated with $L$. braziliensis or L. infantum protein extracts at a concentration of $1 \mu \mathrm{g} /$ well prepared according to Link et al. (2017). Rabbit sera, with anti-peptide polyclonal antibodies, and the second antibody (anti-rabbit IgG (whole molecule) peroxidase-Sigma Aldrich) were respectively diluted $1: 200$ and 1:7,500 in plates coated with L. braziliensis protein extract, and 1:100 and 1:10,000 in plates coated with $L$. infantum protein extract.

\section{In vitro Experimental Infection of Macrophages From Rabbits Immunized With the Peptides Chimeric Macrophages in vitro Infection With L. braziliensis and $L$. infantum Promastigote Forms}

After 90 days post immunization, the rabbits were euthanized, and the macrophages were obtained by inoculation of $120 \mathrm{~mL}$ cold PBS buffer $1 \mathrm{x}(\mathrm{pH}$ 7.4) in the peritoneal cavity. The PBS was collected and transferred to a tube and maintained on ice. The material collected was centrifuged at $1,800 \mathrm{x} \mathrm{g}$, for $10 \mathrm{~min}$ at $4^{\circ} \mathrm{C}$. The pellet was washed with PBS buffer $1 \mathrm{x}(\mathrm{pH}$ $7.4)$, and centrifuged $\left(1,800 \mathrm{xg}\right.$, for $10 \mathrm{~min}$ at $\left.4^{\circ} \mathrm{C}\right)$. The pellet was resuspended in RPMI $1640+20 \%$ FBS $+10 \%$ penicillinstreptomycin and counted in a Neubauer chamber. For in vitro infection, the parasites were obtained from cultures of $L$. braziliensis and L. infantum separately cultivated in biphasic brain heart infusion medium until stationary phage (5 days). The parasites were harvested from culture media, centrifuged twice with PBS for $15 \mathrm{~min}, 1,000 \mathrm{x} \mathrm{g}$ at $10^{\circ} \mathrm{C}$, resuspended in RPMI $1640+20 \%$ FBS $+10 \%$ penicillin-streptomycin, and counted in a Neubauer chamber. For the in vitro infection, 500 $\mu \mathrm{L}$ of parasite suspension were added to each well containing the adhered macrophage cells $\left(1 \times 10^{5}\right.$ cells/well $)$. The parasites were added in a proportion of $15: 1$ (parasites: cells) $\left(1.5 \times 10^{6}\right.$ parasites/well) and were incubated at $37^{\circ} \mathrm{C}$ and $5 \% \mathrm{CO}_{2}$. Next, the RNA was extracted 48 and $72 \mathrm{~h}$ post infection (p.i.) to analyze cytokines, inducible nitric oxide synthase (iNOS) expression, and the parasite load.

\section{Evaluation of Cytokines and iNOS mRNA Expression by Real Time PCR (RT-qPCR)}

A reverse transcriptase and quantitative real time PCR (RTqPCR) was performed to assess the expression of mRNAs of cytokines and iNOS in blood samples, collected between 48 and $72 \mathrm{~h}$ a.f.i. in rabbits, and the peritoneal macrophages from immunized rabbits (90 days a.f.i.) after the in vitro infection.

Total RNA of the samples was extracted using RNeasy Mini Kit (QIAGEN@), according to the manufacturer's instructions. To remove contaminating genomic DNA from RNA samples, a TURBO DNase-free kit (Invitrogen $囚$ ) was used. The samples were quantified by spectophometers, and $150 \mathrm{ng}$ of isolated RNA was reverse transcribed to cDNA using a First Strand cDNA Synthesis kit (Thermo Scientific $\left(\right.$ ) ) with oligos $\mathrm{dT}_{15}$. Complementary DNA was mixed with 10 pmol of each genespecific marker and $2.5 \mu \mathrm{L}$ of SYBR Green PCR Master Mix (Applied Biosystem). The mRNA expression of cytokines and iNOS was assessed using StepOnePlus Real-Time PCR System (Thermo Scientific). Data analysis was performed by the Livak method $\left(2^{-\Delta \Delta \mathrm{Ct}}\right)$ (Livak and Schmittgen, 2001) using the housekeeping genes glyceraldehyde 3-phosphate dehydrogenase (GAPDH) and beta-actin (ACTB) to normalize mRNA expression.

\section{DNA Extraction From in vitro Macrophage Infection}

Total DNA of samples was extracted using the Dynabeads ${ }^{\mathrm{TM}}$ DNA DIRECT ${ }^{\mathrm{TM}}$ Universal kit (Invitogen, Vilnius, Lituania), according to the manufacturer's instructions. The DNA eluate was stored at $-20^{\circ} \mathrm{C}$ until its use in qPCR analysis.

Parasite Load by Quantitative Real-Time PCR (qPCR) The qPCR reactions were performed with $5 \mu \mathrm{L}$ DNA; 2X KAPA Probe Fast ABI Prism $\AA$ from KapaBiosystem; $200 \mathrm{nM}$ DpolyAF ( $5^{\prime}$ GACDGTGAATTACAGGHTGC $3^{\prime}$ ) and DpolyAR (5' ATACTTGCAGCAGCACATCG $3^{\prime}$ ) primers and $100 \mathrm{nM}$ DpolyAS probe (5'FAM- TCACTTGCACHCCAGATK -NFQ$\mathrm{MGB}^{\prime}$ ) specific for the DNA polymerase A of Leishmania sp. Cycling conditions were a first step at $95^{\circ} \mathrm{C}$ for $10 \mathrm{~min}$, followed by 40 cycles at $94^{\circ} \mathrm{C}$ for $30 \mathrm{sec}$ and $58^{\circ} \mathrm{C}$ for $30 \mathrm{~min}$. The amplifications were performed in a QuantStudio ${ }^{\mathrm{TM}} 3$ (Applied 

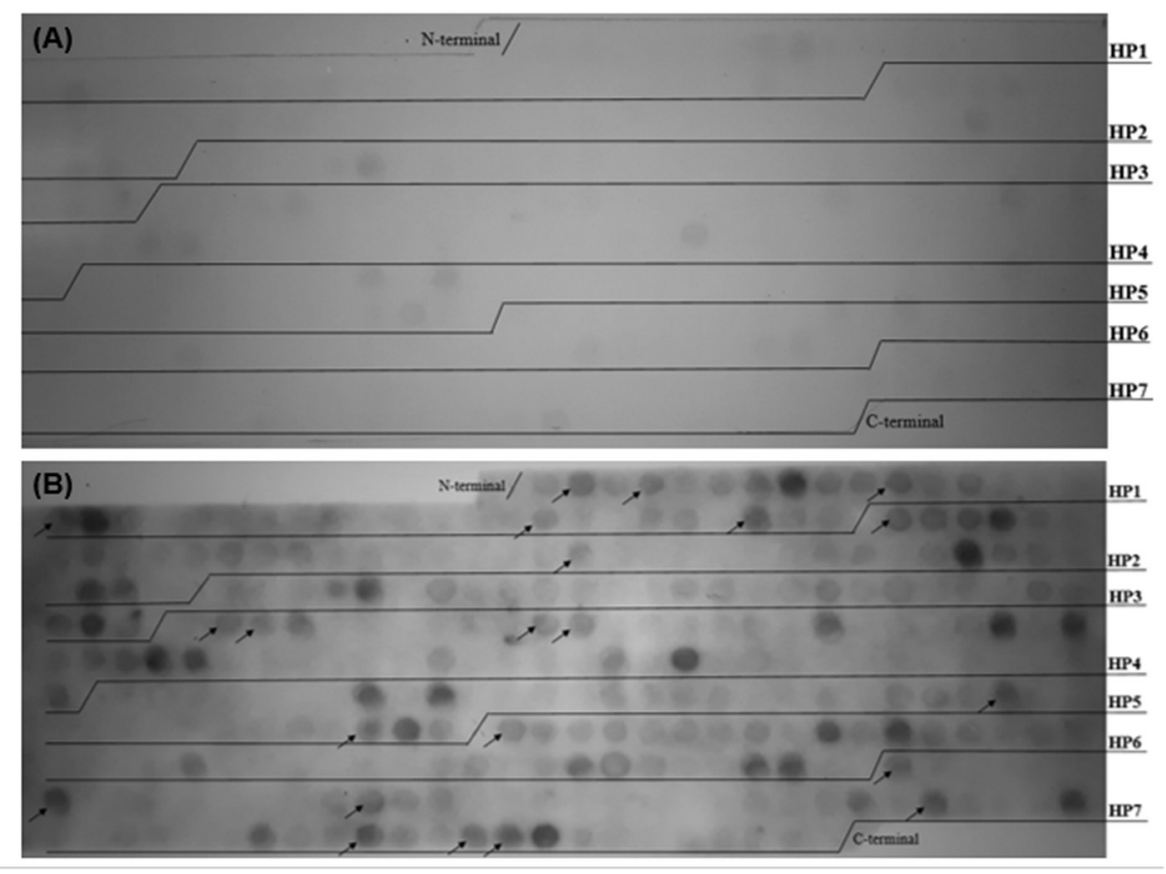

FIGURE 3 | Histone proteins sequences were spot synthesized by overlapping pentadecapeptides offset by three amino acids aimed at selecting and evaluating the reactivity of epitopes on these sequences. Reactivity of peptides originated from histone proteins of Leishmania spp. with anti-L. braziliensis immunoglobulins G. (A) Reactivity of peptides with healthy patient serum without anti-Leishmania spp. IgG. (B) Reactive spots immunodetected by patient serum with antibodies for $L$.

braziliensis and not cross-reacted with healthy patient serum (without anti-Leishmania spp. IgG). The arrows indicate the 22 peptides selected by the immunoassay.

Biosystems, USA). Standard calibration curves were constructed by serial dilution of DNA extracted samples of L. braziliensis from 10 to $0.001 \mathrm{ng}$.

\section{Statistics Analyses}

The results were presented as means \pm SD. Differences in antibody titers, parasite load and cytokine production were assessed by a two-way ANOVA followed by a Tukey HSD comparison test. All statistical analysis was performed using GraphPad Prism version 7.0 software. A $p$-value of $<0.05$ was considered statistically significant.

\section{RESULTS}

\section{Peptide Selection: In silico and in vitro Analysis}

First, the proteins HP1 and HP2 from L. amazonensis were compared with the protein HP6 from L. braziliensis; all three proteins correspond to the histone subunit H3. The analysis showed that between the proteins HP1 and HP6 similarity is $84.6 \%$ and identity is $94.6 \%$. For proteins HP2 and HP6, similarity is $85.4 \%$ and identity is $95.4 \%$. Consequently, the similarity and identity of the protein sequences were analyzed with $L$. infantum histone subunit fractions. The parameters of similarity and identity were not analyzed for HP3, because the protein sequence of histone subunit fraction $\mathrm{H} 1$ was not found for L. braziliensis and L. infantum.

\section{Immunodetection}

The spot synthesis of the seven histone sequences (HP1, HP2, HP3, HP4, HP5, HP6, and HP7) generated 302 spots, such that each spot was a different pentadecapeptide. The reactive epitopes were immunodetected by patient serum with anti-L. braziliensis antibodies. Twenty-two spots were selected, derived from almost all seven histone sequences analyzed. The 22 spots were named $\mathrm{P}_{\mathrm{H}} 2, \mathrm{P}_{\mathrm{H}} 4, \mathrm{P}_{\mathrm{H}} 11, \mathrm{P}_{\mathrm{H}} 17, \mathrm{P}_{\mathrm{H}} 31, \mathrm{P}_{\mathrm{H}} 37, \mathrm{P}_{\mathrm{H}} 40, \mathrm{P}_{\mathrm{H}} 61, \mathrm{P}_{\mathrm{H}} 109, \mathrm{P}_{\mathrm{H}} 110$, $\mathrm{P}_{\mathrm{H}} 118, \mathrm{P}_{\mathrm{H}} 119, \mathrm{P}_{\mathrm{H}} 190, \mathrm{P}_{\mathrm{H}} 202, \mathrm{P}_{\mathrm{H}} 205, \mathrm{P}_{\mathrm{H}} 245, \mathrm{P}_{\mathrm{H}} 251, \mathrm{P}_{\mathrm{H}} 260$, $\mathrm{P}_{\mathrm{H}} 276, \mathrm{P}_{\mathrm{H}} 290, \mathrm{P}_{\mathrm{H}} 293$, and $\mathrm{P}_{\mathrm{H}} 294$. The membrane was tested with serum from volunteer healthy patients, without antibodies for Leishmania spp., to verify that these reactions were specific (Figure 3).

\section{In silico Analysis of Peptide Sequences}

Bioinformatics tools (Peptide 2.0, IPC, PepCalc) enabled the analysis of peptide sequences and those with a hydrophobicity lower than 55\% were selected for the next steps of the study (Table 1). In fact, hydrophobic peptides are insoluble hindering their use. The Leishmania spp. histone proteins sequences used in this study were $3 \mathrm{D}$ modeled using the $\mathrm{X}$ ray diffraction structure of histones as templates. The structures of HP1, HP2 and HP6 were constructed by homology with histone H3. The tridimensional structure HP4 was constructed with histone $\mathrm{H} 2 \mathrm{~B}$; histone $\mathrm{H} 2 \mathrm{~A}$ was used for $\mathrm{HP}$; and for HP7, the template was constructed by homology with histone $\mathrm{H} 4$. 
TABLE 1 | In silico analysis of reactive peptides.

\begin{tabular}{|c|c|c|c|c|c|c|c|}
\hline Peptides & $\begin{array}{c}\text { Molecular } \\
\text { weight (g/mol) }\end{array}$ & $\begin{array}{l}\text { Iso-electric } \\
\text { Point }\end{array}$ & $\begin{array}{l}\text { Net } \\
\text { charge }\end{array}$ & $\begin{array}{l}\text { Hydrophobicity } \\
\text { (\%) }\end{array}$ & $\begin{array}{l}\text { Peptide } \\
\text { source }\end{array}$ & $\begin{array}{l}\text { CD4 T cell immunogenicity } \\
\text { prediction }\end{array}$ & $\begin{array}{l}\text { T cell class I pMHC } \\
\text { immunogenicity prediction }\end{array}$ \\
\hline $\mathrm{P}_{\mathrm{H}} 2^{*}$ & 1649.89 & 9.66 & 4 & 20 & $\mathrm{H} 3.1$ & 71.85 & -0.27 \\
\hline $\mathrm{P}_{\mathrm{H}} 11^{*}$ & 1864.19 & 11.37 & 3 & 40 & H3.1 & 63.99 & 0.61 \\
\hline $\mathrm{P}_{\mathrm{H}} 17^{\star}$ & 1747.03 & 9.1 & 1.9 & 40 & H3.1 & 45.92 & -0.02 \\
\hline $\mathrm{P}_{\mathrm{H}} 40^{*}$ & 1750.04 & 11.55 & 4 & 26.67 & H3.2 & 60.96 & 0.06 \\
\hline $\mathrm{P}_{\mathrm{H}} 61^{*}$ & 1727.96 & 10.36 & 2 & 33.33 & $\mathrm{H} 3.1$ & 54.26 & -0.29 \\
\hline $\mathrm{P}_{\mathrm{H}} 109^{*}$ & 1627.88 & 5.21 & -0.1 & 53.33 & $\mathrm{H} 2 \mathrm{~B}$ & 55.89 & -0.11 \\
\hline $\mathrm{P}_{\mathrm{H}} 110^{*}$ & 1659.97 & 5.21 & -0.1 & 53.33 & $\mathrm{H} 2 \mathrm{~B}$ & 46.26 & -0.47 \\
\hline$P_{H} 118$ & 1825.12 & 9.95 & 1.2 & 60 & $\mathrm{H} 2 \mathrm{~B}$ & 47.46 & 0.15 \\
\hline $\mathrm{P}_{\mathrm{H}} 245$ & 1605.95 & 5.83 & -0.1 & 66.67 & $\mathrm{H} 4$ & 72.28 & 0.34 \\
\hline $\mathrm{P}_{\mathrm{H}} 251^{*}$ & 1523.69 & 10.47 & 1.1 & 46.67 & $\mathrm{H} 4$ & 56.31 & -0.34 \\
\hline $\mathrm{P}_{\mathrm{H}} 260^{*}$ & 1827.16 & 11.15 & 2.2 & 40 & $\mathrm{H} 4$ & 43.00 & -0.24 \\
\hline $\mathrm{P}_{\mathrm{H}} 276^{\star}$ & 1713 & 10.66 & 5 & 26.67 & $\mathrm{H} 4$ & 84.88 & -1.10 \\
\hline $\mathrm{P}_{\mathrm{H}} 290^{*}$ & 1882.12 & 4.79 & -1 & 40 & $\mathrm{H} 4$ & 42.78 & 0.17 \\
\hline $\mathrm{P}_{\mathrm{H}} 293^{\star}$ & 1719.87 & 3.96 & -2.1 & 33.33 & $\mathrm{H} 4$ & 46.25 & 0.24 \\
\hline $\mathrm{P}_{\mathrm{H}} 294^{*}$ & 1776.92 & 4.57 & -1.1 & 26.67 & $\mathrm{H} 4$ & 53.46 & 0.15 \\
\hline
\end{tabular}

The evaluated parameters are mass weight, iso-electric point, net charge, and hydrophobicity. The ${ }^{*}$ ) indicates the peptides that present hydrophobicity lower than $55 \%$.

According to these alignments, the tridimensional structures of the proteins HP1, HP2, HP5, and HP7 were constructed (Figure 4). The alignment of HP1 and HP2 sequences was made with the same template from histone $\mathrm{H} 3$, so these two proteins have the same $3 \mathrm{D}$ structure. After constructing the tridimensional structures by homology modeling, the peptides were located on the structures using the Swiss-PDB Viewer program. For $\mathrm{HP} 1$, the reactive peptides $\mathrm{P}_{\mathrm{H}} 11, \mathrm{P}_{\mathrm{H}} 17, \mathrm{P}_{\mathrm{H}} 31$, $\mathrm{P}_{\mathrm{H}} 37$, and $\mathrm{P}_{\mathrm{H}} 61$ were highlighted on the histone protein structure. The same was performed for HP5 with peptides $\mathrm{P}_{\mathrm{H}} 190$ and $\mathrm{P}_{\mathrm{H}} 202$, and for $\mathrm{HP} 7$ with peptides $\mathrm{P}_{\mathrm{H}} 276, \mathrm{P}_{\mathrm{H}} 290, \mathrm{P}_{\mathrm{H}} 293$, and $\mathrm{P}_{\mathrm{H}}$ 294. After these analyses, the reactive peptides were evaluated by Epitopia server (Figure 5) and IEDB Analysis Resource to verify their immunogenic characteristics (Table 1). After all these analyses, the amino acid sequences of the selected peptides were BLASTed against Leismania spp. histone proteins sequences to verify the identity between them.

\section{Chemical Synthesis of Selected Peptides and Their Evaluation by Indirect ELISA}

The synthesis of peptides resulted in $2.5 \mathrm{mg}$ of each soluble molecule, which were resuspended in $1 \mathrm{~mL}$ of ultrapure water. Each peptide was tested as an antigen in an iELISA assay at concentrations of $0.25,0.5$, and $1 \mu \mathrm{g} / \mathrm{mL}$.

The results showed that all the peptides showed immunoreactivity in patient serum for anti-L. braziliensis $(n=13)$ and for anti- L. infantum $(n=10)$ antibodies. In the
iELISA test for patient serum with anti- L. braziliensis antibodies, the best results were observed for peptides $\mathrm{P}_{\mathrm{H}} 31$, and $\mathrm{P}_{\mathrm{H}} 293$, which reached an absorbance 2.5-fold higher than the positive and negative controls. These results were observed for the peptides tested under the conditions of $0.25 \mu \mathrm{g} / \mathrm{mL}$ of antigen, $1: 100$ of serum and 1:7,500 of conjugate in the case of $\mathrm{P}_{\mathrm{H}} 31$; and of $0.5 \mu \mathrm{g} / \mathrm{mL}$ of antigen, 1:200 of serum and 1:10,000 of conjugate for $\mathrm{P}_{\mathrm{H}} 293$ (Table 2). For anti- L. infantum antibodies, the best results were observed for $\mathrm{P}_{\mathrm{H}} 202$ and $\mathrm{P}_{\mathrm{H}} 293$ under the same conditions of $0.5 \mu \mathrm{g} / \mathrm{mL}$ of antigen, $1: 200$ of serum, $1: 10,000$ of conjugate, where the absorbance was 2.5 times higher from positive and negative controls (Table 2). According to these test results, the peptides $\mathrm{P}_{\mathrm{H}} 31, \mathrm{P}_{\mathrm{H}} 202$, and $\mathrm{P}_{\mathrm{H}} 293$ were selected and analyzed in biological assays as antigen candidates.

\section{Production and Evaluation of Peptides \\ Chimeric Structure}

The encapsulation of peptides resulted in five samples of chimeric molecules at a concentration of $500 \mu \mathrm{g} / \mathrm{mL}$. To formulate the antigen for animal immunization, each sample was resuspended in $1 \mathrm{~mL}$ of adjuvant resulting in a final concentration of $500 \mu \mathrm{g} / \mathrm{mL}$. The antibody response with the entrapped mix of peptides, evaluated by iELISA test showed that producing antipeptides polyclonal antibodies 15 days a.f.i. was feasible. This production was detected by all the kinetics evaluated (until 90 days a.f.i.) for both $L$. braziliensis and L. infantum protein extracted antigen (Figure 6). 

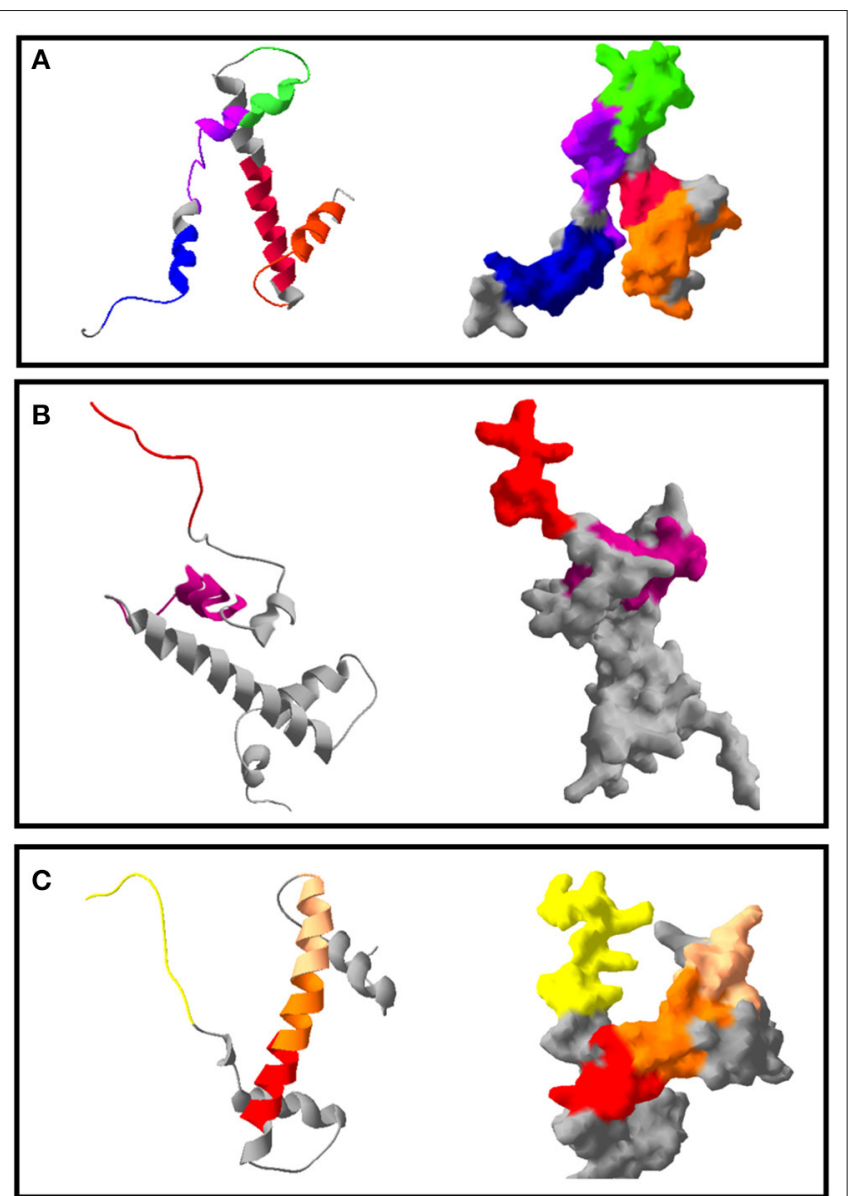

FIGURE 4 | Tridimensional model of Leishmania spp. histones and the position of the immunodominant peptides selected. The colors indicate the different epitope regions of this sequence, which were immunodetected by anti-L. braziliensis IgG on the Spot Synthesis membrane. (A) Ribbon format and solid surface format of the protein HP1. In blue: $P_{H} 11$; in purple: $P_{H} 17$; in pink: $P_{H} 31$; in orange: $P_{H} 37$ and in green: $P_{H} 61$. (B) Ribbon and solid surface format of the protein HP5. In pink: $P_{H}$ 190; in red: $P_{H}$ 202. (C) Ribbon and solid surface format of the protein HP7. In yellow: $\mathrm{P}_{H} 276$; in red: $\mathrm{P}_{\mathrm{H}} 290$; in orange: $\mathrm{P}_{\mathrm{H}} 293$; in light pink: $\mathrm{P}_{\mathrm{H}} 294$.

\section{Cytokines and Effector Molecule Induction by the Chimeric Molecules}

To understand how the immunization could activate the immune response in the different groups, the expression of inflammatory Th-1 inductor cytokines (IL-12, IFN- $\gamma$ ), Th2 inductor cytokine (IL-4), regulatory cytokine (IL-10) and effector molecule (nitric oxide) inductor (iNOS) was measured 48 and $72 \mathrm{~h}$ a.f.i. in the blood of the rabbits. The peptide mix (Group 2) induced high expression of all the molecules evaluated $72 \mathrm{~h}$ a.f.i., compared with the other groups; this was significant, with a $P$-value $>$ 0.01 . High expression of IL-12 and iNOS was observed in the control group $48 \mathrm{~h}$ a.f.i. Group 1 (adjuvant) only induced iNOS expression 48 h a.f.i. (Figure 7A).

After the collection of peritoneal macrophages, from rabbits previously immunized with the peptides mix, infection in culture with L. braziliensis was performed and analyzed after 48 and $72 \mathrm{~h}$. High expression was observed in the rabbits immunized with the peptide mix, showing a significant difference compared with the other groups $(P$-value $>0.01)$ at $48 \mathrm{~h}$ p.i., which decreased by $72 \mathrm{~h}$ p.i. In addition, the IFN- $\gamma$ expression was increased in this group $72 \mathrm{~h}$ p.i. and showed a significant difference in relation to the negative control group, while iNOS expression was the same at both times evaluated. The peptide mix group (Group 2) also induced IL- 4 and TGF- $\beta 72 \mathrm{~h}$ p.i. and showed a significant difference in relation with the other groups $(P$-value $>0.1)$. The adjuvant group (Group 1) showed increased expression of all the cytokines evaluated and iNOS $72 \mathrm{~h}$ p.i., while the control group only induced the expression of iNOS $72 \mathrm{~h}$ p.i. (Figure 7B).

Peritoneal macrophages were also infected in culture with $L$. infantum and high expression of IL-12, TGF- $\beta$ and iNOS was observed $48 \mathrm{~h}$ p.i., showing a significant difference compared with the other groups $(P$-value $>0.01)$, while IL-4 and IFN$\gamma$ also increased $72 \mathrm{~h}$ p.i. in the peptide mix group (Group 2). No significant expression was observed in the other groups after infection by this parasite (Figure 7C).

Regarding parasite load, a significant reduction in the load of Leishmania was observed in macrophages from rabbits immunized with the peptide mix in relation to the negative control and adjuvant group at $48 \mathrm{~h}(P$-value $>0.0001)$ and $72 \mathrm{~h}(P$-value $>0.1)$ (Figure 8). The parasitism in macrophages from the adjuvant group showed an increase compared with the negative control group, which is probably related to a nonspecific cellular activation caused by this compound that favors Leishmania infection in these cells. Finally, these results indicate an activation of the macrophages by the peptide mix, facilitating the neutralization of Leishmania amastigotes.

\section{DISCUSSION}

Leishmania spp. are intracellular parasites that have complex mechanisms to survive and multiply inside the host system of phagocytic mononuclear cells. The production of antibodies and/or cellular immunity during host infection is induced because most Leishmania antigens are recognized by the host system. However, the immune response to some of these antigens does not protect the host. In other cases, it may contribute to intensifying the pathological response, due to cross-reaction with the host's biomolecules (Handman, 2001). In addition, some studies report that the capacity to respond to Leishmania antigens varies from individual to individual. Thus, the diagnosis of our vaccine against leishmaniosis requires different antigens (polyvalent) capable of inducing a protective immune response in most of the population and which can be produced in large scale (Mukherjee et al., 2013).

To achieve higher antigenicity, proteins were selected to target antigenic epitopes and then constructing a chimeric molecule that has greater antigenicity. Thus, seven protein sequences of Leishmania spp. histones were selected, which are one of the intracellular immunogenic molecules from this parasite. The core histone of eukaryotic species comprises two paired dimers $\mathrm{H} 2 \mathrm{~A} / \mathrm{H} 2 \mathrm{~B}$ and $\mathrm{H} 3 / \mathrm{H} 4$ and a linker histone $\mathrm{H} 1$, which constitute 


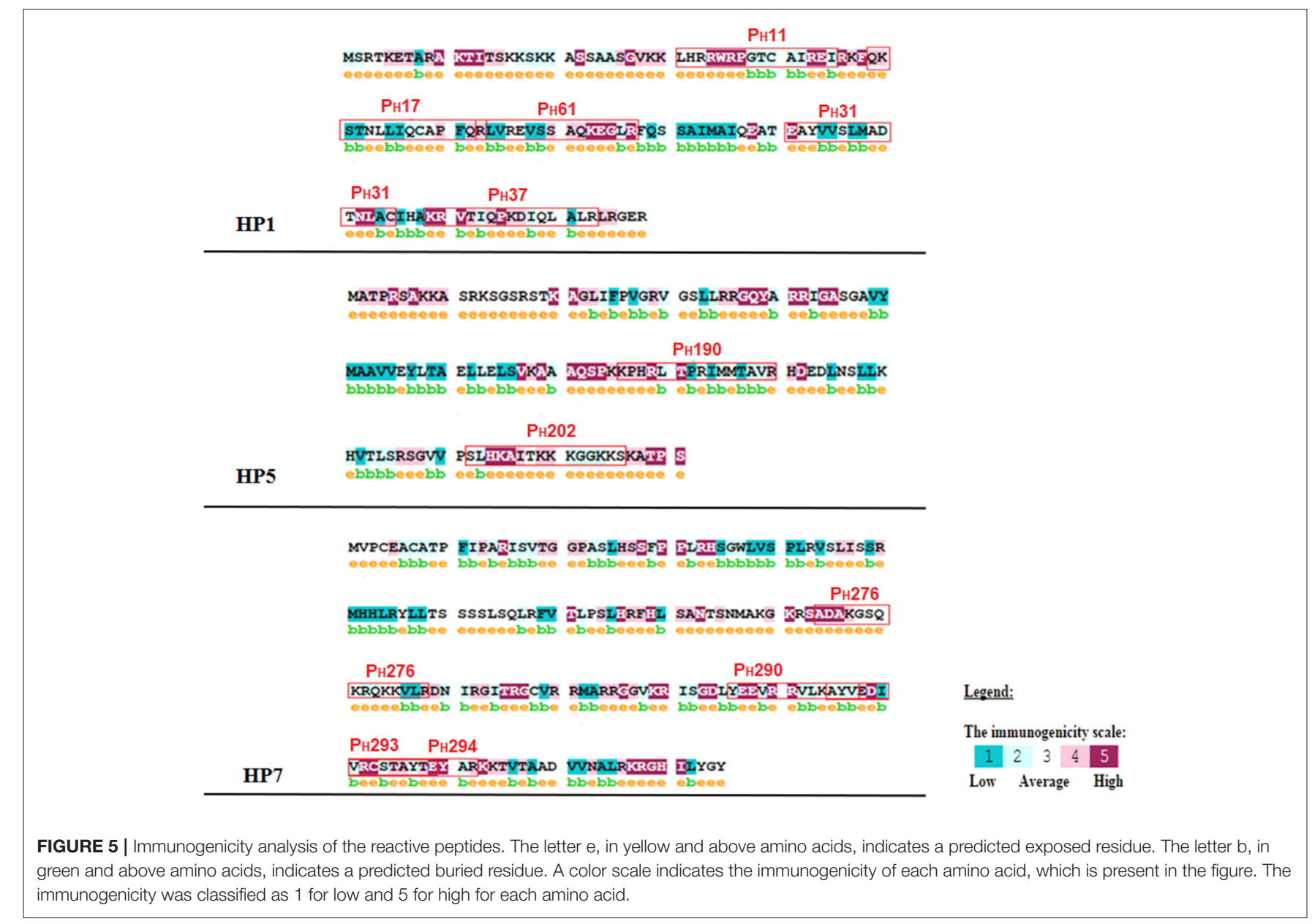

TABLE 2 | Indirect ELISA reaction parameters standardized for peptides PH31, $\mathrm{PH} 202$, and $\mathrm{PH} 293$.

\begin{tabular}{|c|c|c|c|c|}
\hline & $\begin{array}{l}\text { Peptide } \\
(\mu \mathrm{g} / \mathrm{mL})^{\mathrm{a}}\end{array}$ & $\begin{array}{l}\text { Serum }^{b} \\
(N=23)\end{array}$ & $\begin{array}{c}\text { Second } \\
\text { antibody }^{\mathrm{c}}\end{array}$ & Absorbance \\
\hline \multicolumn{5}{|c|}{ Anti-L. braziliensis IgG } \\
\hline $\mathrm{P}_{\mathrm{H}} 31$ & 0.25 & $1: 100$ & $1: 7,500$ & 0.132 \\
\hline $\mathrm{P}_{\mathrm{H}} 293$ & 0.5 & $1: 200$ & $1: 10,000$ & 0.120 \\
\hline \multicolumn{5}{|c|}{ Anti-L. infantum IgG } \\
\hline $\mathrm{P}_{\mathrm{H}} 202$ & 0.5 & $1: 200$ & $1: 10,000$ & 0.123 \\
\hline$P_{H} 293$ & 0.5 & $1: 200$ & $1: 10,000$ & 0.137 \\
\hline
\end{tabular}

${ }^{a}$ Antigen (peptide) concentration on indirect ELISA assay; ${ }^{b}$ Patients serum concentration; ${ }^{c}$ Second antibody concentration; ${ }^{d}$ The absorbance of negative serum samples was 0.05 .

some of the most well-conserved molecules among these organisms. For these characteristics, these molecules are good protein candidates to screen conserved immunogenic epitopes among the different Leishmania spp. (Baharia et al., 2014). The histone protein sequences derived from L. amazonensis were named HP1, HP2, and HP3, while those derived from L. braziliensis were named HP4, HP5, HP6, and HP7. The proteins HP1, HP2, and HP6 correspond to histone fraction type $\mathrm{H} 3$, protein $\mathrm{HP} 3$ corresponds to $\mathrm{H} 1, \mathrm{HP} 4$ to $\mathrm{H} 2 \mathrm{~B}$; $\mathrm{HP} 5$ to $\mathrm{H} 2 \mathrm{~A}$, and protein HP7 corresponds to H4. These sequences were evaluated according to the similarity and identity among them. The results showed that the sequences have more than $84 \%$ similarity and $90 \%$ identity. When compared with $L$. infantum histones, the score varies from 52 to $92 \%$ similarity and 49 to $82 \%$ identity. The results indicate good similarity and identity between the Leishmania species, which is desirable to enable the selection of epitopes with amino acid sequences that can be recognized by different species from the parasite and formulate an antigen capable of inducing an immune response for different Leishmania species. In the last few years, several studies have described the isolation and application of different biomolecules that present protective activity and are potentially good antigen candidates for a leishmaniosis vaccine (Singh and Sundar, 2012; De Brito et al., 2018; Thomaz-Soccol et al., 2018). These antigens are originated from proteases and other molecules actively secreted by the parasites or from membrane and intracellular proteins. Among these molecules are histones, which are highly conserved antigens produced by Leishmania spp. and even though they are not secreted by the parasites they can induce a potent immune response. These antigens are released during infection after the elimination of intracellular 

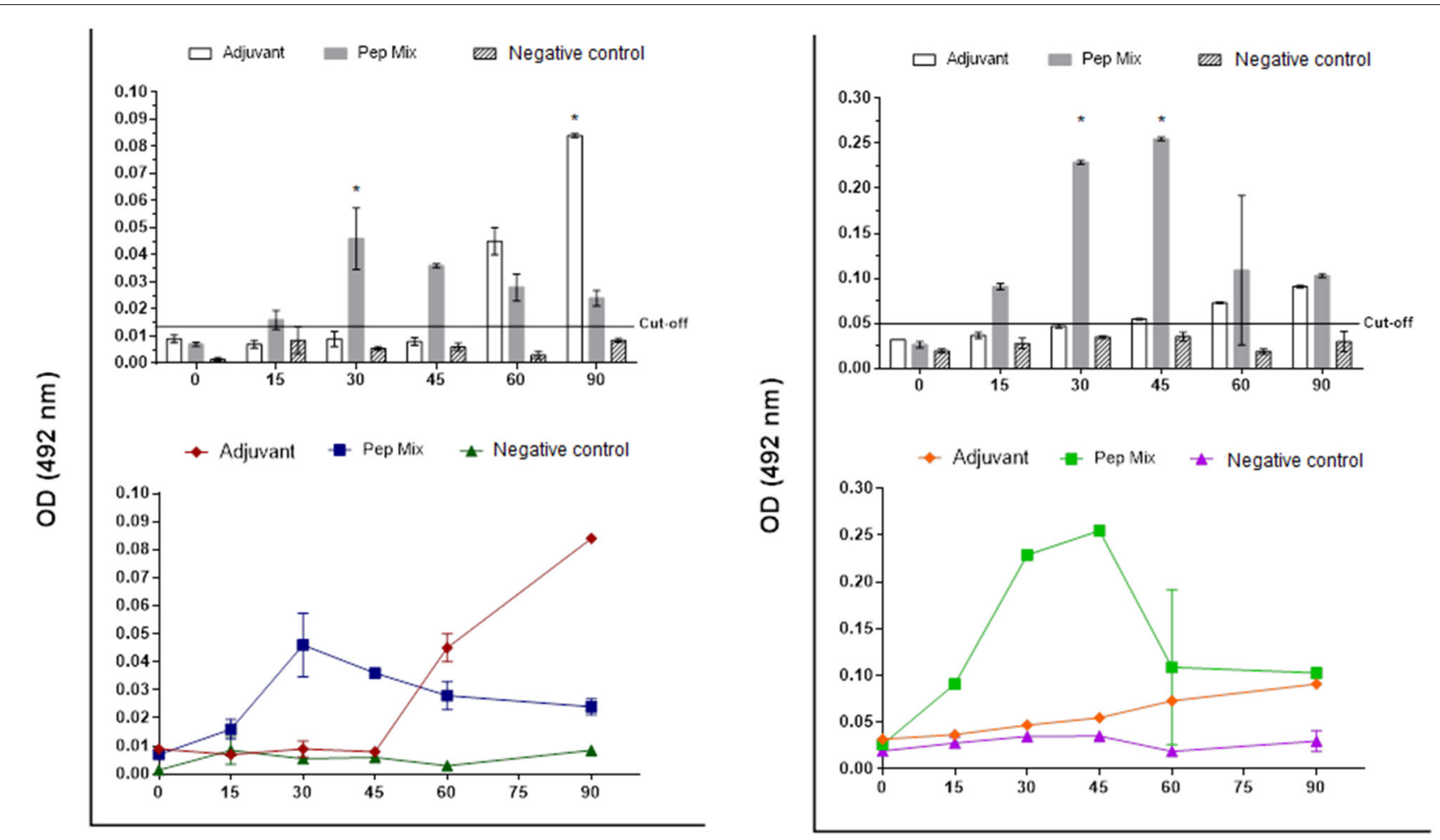

L. braziliensis

Immunization period (days)

\section{L. infantum}

FIGURE 6 | Reactivity of anti-peptide polyclonal antibodies against $L$. braziliensis and/or $L$. infantum protein extract antigen tested by indirect ELISA assay. Kinetics of IgG production for 90 days in: Group 1: rabbits immunized with aluminum hydroxide (adjuvant). Group 2: rabbits immunized with peptides mix entrapped in liposomes. Group 3: non immunized rabbits (negative control). The red line indicates the cut-off value 0.014 for L. braziliensis and $0.050 \mathrm{~L}$. infantum. Statistical test two-way ANOVA followed by a Tukey HSD comparison test ${ }^{*} P<0.05$.

amastigotes by the active macrophage, or by the spontaneous cystolysis of amastigotes inside the infected cells (Carrión et al., 2009). Moreover, these antigens are capable of modulating the host immune response because they do not suffer from its immune selective pressure, unlike surface and secreted proteins (Chang et al., 2003).

The antigenicity of the core histones (H2B, H2A, H3, and $\mathrm{H} 4)$ have been reported in studies as being recognized by sera from cutaneous (CL) and mucocutaneous leishmaniosis (MCL) human patients and by canine visceral leishmaniosis (CVL) (Soto et al., 1999; Meddeb-Garnaoui et al., 2010; Souza et al., 2013). The protein $\mathrm{H} 2 \mathrm{~A}$ has been described as the most antigenic core histone and one which can also be recognized by sera from VL human patients (Passos et al., 2005). Other studies report the analysis of histone $\mathrm{H} 2 \mathrm{~A}, \mathrm{H} 3$, and $\mathrm{H} 4$ immunization against $\mathrm{CL}$ by applying the histones individually, in cocktails, or genetically fused to a plasmid. BALB/c mice genetically immunized with the individual histones showed a delay in the development of the lesion, and immunization with the plasmids encoding the histone and the cocktails provided protection against L. major (Carrion et al., 2008). A study by Iborra et al. (2004) evaluated the prophylactic activity of $L$. infantum histones in an animal model for cutaneous leishmaniasis, and reported that the animals immunized with a mixture of the four plasmids encoding the histones $\mathrm{H} 2 \mathrm{~A}, \mathrm{H} 2 \mathrm{~B}, \mathrm{H} 3$, and $\mathrm{H} 4$ developed a specific Th1 response associated with histone-specific production of IFN$\gamma$. Carneiro et al. (2012) also analyzed the immune protection conferred by nucleosomal histones of L. infantum in murine model infected with $L$. braziliensis, and concluded that histone are potential targets for vaccine formulation against $L$. braziliensis since they showed significant inhibition activity for the disease.

To select the most reactive and antigenic peptides from spot synthesized histones, this study evaluated whether the reactive peptides were located in immunogenic regions of the proteins and whether they were able to manifest epitope-like characteristics. The results showed that all the peptides were located in regions with an immunogenicity score higher than 70 $\%$ (Table 1) and the majority of the amino acids of the peptides were considered to be predicted exposed residues (Figure 6). In the last in silico analysis, the peptide sequences were BLASTed against Leishmania spp. protein to evaluate the identity rate between them and to analyze whether the peptide sequences were homologous to Leishmania histones. The results showed that all the peptides sequences analyzed presented more than 
Adjuvant $\square$ Pep. Mix. $\square$ Negative control
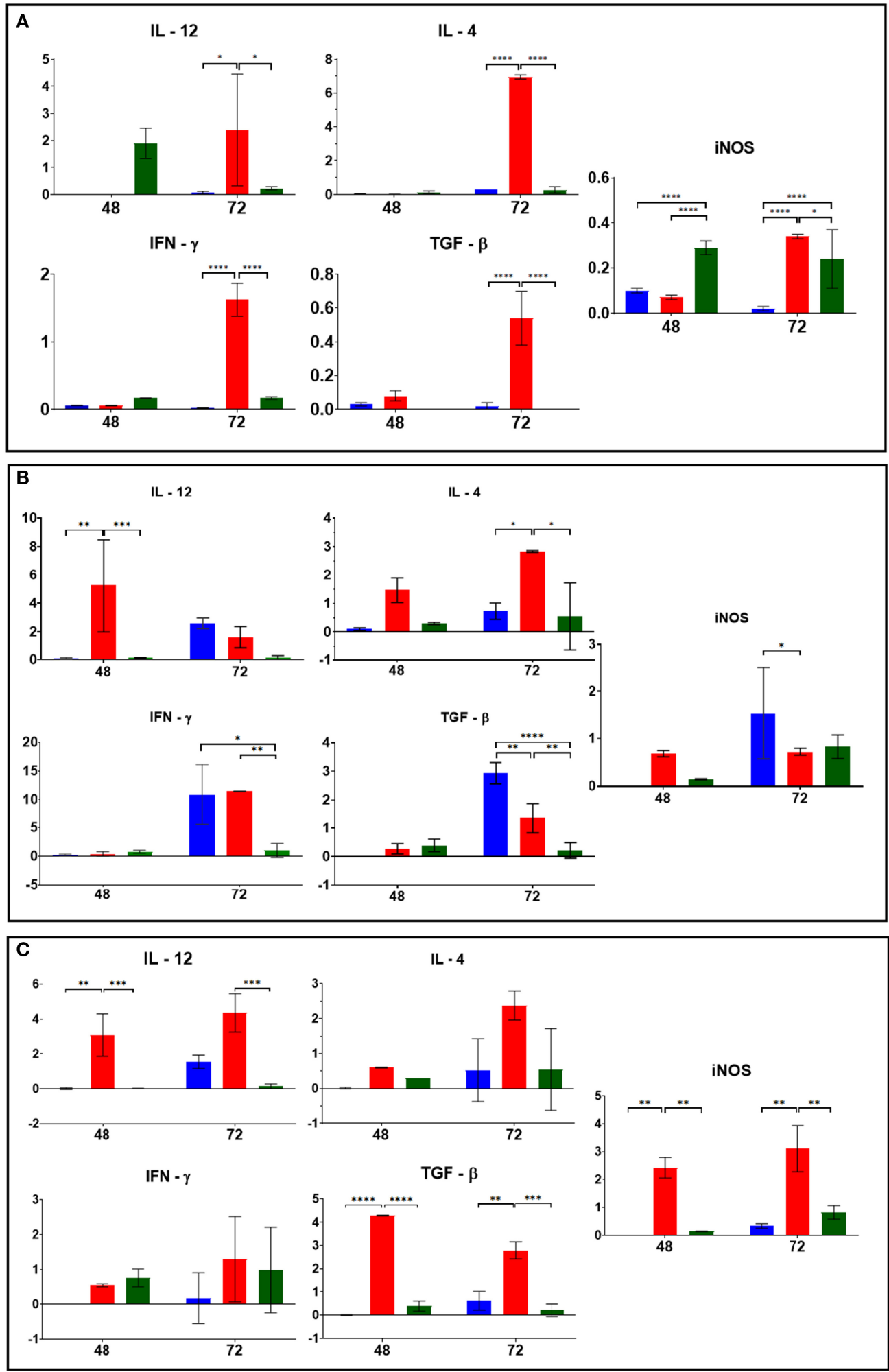

FIGURE 7 | Cytokine (IL-12, IFN $\gamma$, IL-4, and TGF- $\beta$ ) and iNOS mRNA expression were evaluated in blood samples (A) and macrophages from rabbits immunized with adjuvant, or peptides mix, and non-immunized (negative control) after infection by $L$. braziliensis (B) and L. infantum (C). All the results are presented as the mean \pm SD. Statistical test two-way ANOVA followed by a Tukey HSD comparison test ${ }^{\star} P<0.05 ;{ }^{\star \star} P<0.01 ;{ }^{\star \star \star} P<0.001 ;{ }^{\star \star \star \star} P<0.0001$, a comparison was with negative control. 
90\% identity with histone proteins from different Leishmania spp., mainly for L. braziliensis and L. infantum. The results also confirmed the identity of each peptide sequence with its own original histone sequence.

All these in silico analyses resulted in the selection of the peptides $\mathrm{PH} 11, \mathrm{PH} 17, \mathrm{PH} 31, \mathrm{PH} 37$, and $\mathrm{PH} 61$ (histone H3), PH190 and PH202 (histone H2A), and PH276, PH290, PH293, and $\mathrm{PH} 294$ (histone $\mathrm{H} 4$ ), which presented a response score for in silico CD4 analysis ranging from 42.78 to 84.9 (Table 1). The results of the iELISA study showed that some peptides did not show a satisfactory difference between serum positivity and negativity. It may not be able to induce a mimetic response like the parasite. Thus, the peptides selected according to these specifications were PH31, PH202, and PH293. Peptide PH31 showed good reactivity against anti-L. braziliensis antibodies, as did PH202 for anti-L. infantum antibodies. Peptide PH293 showed good reactivity against anti-L. braziliensis antibodies and for L. infantum IgG. We have shown here that the humoral response (optical density) was low compared with serological tests, where the differences between positive and negative are 8 to 10 times greater. However, the peptides were able to mimic the antigen. The milestone in Leishmania histone antigenicity studies was the screening of cDNA expression libraries using sera from infected dogs. The first report on a specific immune response against histones during infection was the identification of histone $\mathrm{H} 2 \mathrm{~A}$ from $L$. infantum by immunoscreening with CVL serum (Soto et al., 1992). Later, a study by Soto et al. (1994) reported the isolation of a cDNA clone coding L. infantum histone $\mathrm{H} 3$ by a strong immunoreaction with VL sera. In a subsequent study, the authors demonstrated that the histones $\mathrm{H} 2 \mathrm{~B}$ and $\mathrm{H} 4$ from L. infantum were also recognized by VL sera (Soto et al., 1999). Moreover, a study by Lakhal et al. (2012) reported the diagnostic performance of a crude Leishmania histone used as antigen in an ELISA assay in which the reactivity was accessed by sera from VL patients. The results showed the ability of this antigen to discriminate between VL cases and healthy controls. These studies report the ability and capability of histone proteins at being recognized by humoral immune molecules, which affirms their antigenicity potential for use as antigen molecules in diagnosis. This also corroborates our results for the anti-peptide histone humoral response tests, in which the reactivity of the peptides against human patient serum with anti- L. braziliensis or anti- L. infantum antibodies was verified. The peptides did not achieve the expected yield, as shown by Leishmania protein extract or recombinant proteins. This is because, in comparison to peptides, the protein extracts and recombinant proteins offer a greater variety of reactive epitopes, which consequently can recruit a greater immune response. This hypothesis reinforces the need for testing different combinations of molecules/peptides designed for anti-Leishmania vaccines to induce a strong immune response (Alonso and Soto, 2014).

After this step, we selected three reactive peptides $\left(\mathrm{P}_{\mathrm{H}} 31\right.$, $\mathrm{P}_{\mathrm{H}}$ 202, and $\mathrm{P}_{\mathrm{H}}$ 293) and added three more previously selected by our research group (Thomaz-Soccol et al., 2015; Link et al., 2017; Guedes et al., 2019), which were then encapsulated in liposome. This small vesicle structure was selected to encapsulate the peptides due to its properties of biocompatibility, low toxicity, size, and hydrophobic and hydrophilic character. Moreover,

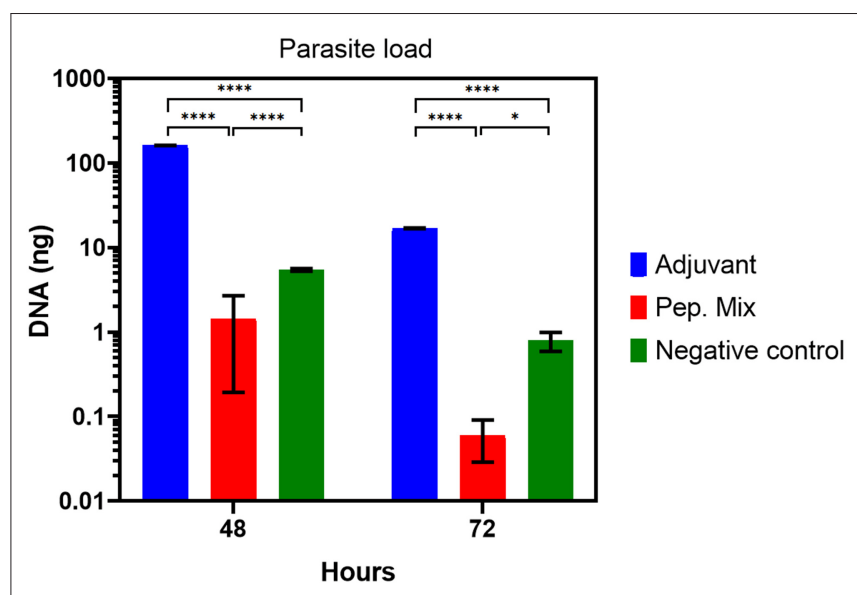

FIGURE 8 | Parasite load from in vitro infection with Leishmania of macrophages from rabbits immunized with adjuvant, or peptides mix, and non-immunized (negative control), 48 or $72 \mathrm{~h}$ post-infection. All the results are presented as the mean $\pm \mathrm{SD}$. Statistical test two-way ANOVA followed by a Tukey HSD comparison test ${ }^{\star} P<0.05$; ${ }^{\star \star} P<0.01$; ${ }^{\star \star \star} P<0.001,{ }^{\star \star \star \star} P<$ 0.0001 .

liposome structures avoid decomposition of the entrapped molecules and release them at designed targets, which make them promising systems for drug delivery (Akbarzadeh et al., 2013; Alavi et al., 2017). The antibody response with the entrapped mix of peptides, evaluated by ELISA test, showed that producing antipeptide polyclonal antibodies 15 days after the first immunization was feasible and this production was detected by all the kinetics evaluated for both L. braziliensis and L. infantum protein extract antigen (Figure 6). In both situations, a characteristic curve of antibody response kinetics with plateau phase between 30 and 45 days of immunization was observed. The first 30 days of immunization characterize the primary immune response, where immature B cells are stimulated by the antigen and become active, which induces a more specific antibody for the antigen. With repeated infection (45 days), the secondary immune response is induced when the same antigen stimulates the memory B cells leading to the production of greater quantities of specific antibodies than observed in the primary response (Abbas et al., 2015).

The group immunized only with adjuvant (aluminum hydroxide) presented anti-Leishmania immune response, which confirms its capacity for use as an antigen. Aluminumbased adjuvants are widely used throughout the world, and among the variants, aluminum hydroxide is the chemical most commonly used as an adjuvant. An important function of aluminum hydroxide is stimulating $\mathrm{T}$ cells activation and the expression of co-stimulators on antigen-presenting cells (APCs) (Abbas et al., 2015). Aluminum hydroxide mechanisms of action include depot formation, which facilitate the continued release of antigens, the formation of particulate structures promoting antigen phagocytes by macrophages and B cells, and inflammation induction that results in the activation and recruitment of macrophages (Mutiso et al., 2010; He et al., 2015). Thus, aluminum-based adjuvants can help boost the humoral immunity response by providing Th2 cells and the injection of 
this adjuvant can result in the priming and persistence of Th2 cells producing IL-4, IL-5, and IL-10 (Awate et al., 2013; Beck et al., 2018).

Although the previous analyses were performed by selecting biomolecules that stimulate immune response type B, some tests were performed to evaluate the cytokine profile stimulated by these peptides. These evaluations of cellular immune response sought to verify whether the peptides were capable of inducing a profile of cytokines that can lead to their application as antigens for vaccines. A protocol of in vitro infection was developed to identify the pattern of cytokines expressed during the immunization period and to verify whether differentiated expression of these cytokines occurred to promote a cellular immune response generated by these peptides. The results showed that the peptides induced high expression of iNOS, IL12 , and IFN- $\gamma, 72 \mathrm{~h}$ after first immunization, although there were also increases in the IL- 4 and TGF- $\beta$ expression. This means that the peptide mix was able to induce cellular immune response in rabbits with a cytokine profile that stimulated $\mathrm{T}$ helper 1 (Th1) and $\mathrm{T}$ helper 2 (Th2) responses, but the principal information is that this immunization induced the increase of iNOS, the main NO inductor. The expression of iNOS is induced by IFN- $\gamma$ in macrophages and its activation contributes to controlling the death or replication of intracellular pathogens. High-levels of iNOS are associated with the adaptive phase of immune response and its function of co-factor can contribute to the activation of IL-12 and IFN- $\gamma$ in natural killer (NK) cells (Bogdan, 2015). Although transforming growth factor-beta (TGF- $\beta$ ) is related to the regulatory functions of the immune system, it is known that multifunctional cytokines are implicated in a variety of biological processes by enhancing cellular proliferation, activation, and stimulating cytokines of effector Th17 cells. Th17 cells show an inflammatory profile with the recruitment of neutrophils. These cells are important at the onset of infection since they can recruit more cells to the infection site and favor control of the infection (Oh and Li, 2013; Okamura et al., 2015).

The differentiation of Th1 cells is promoted mainly by IL-12 and IFN- $\gamma$ and occurs in response to pathogens that activate dendritic cells, macrophages and NK cells. This profile of cytokines stimulates phagocytosis, oxidative burst and intracellular pathogen killing, regulates the expression of major histocompatibility complex (MHC), classes I and II, and thus stimulates antigen presentation to T cells (Spelberg and Junior, 2001; Abbas et al., 2015; Cortés et al., 2017). Th2 differentiation is promoted by IL-4, which stimulates high titers of antibody production and activates $B$ cell proliferation. Moreover, Th2 plays an important role in the inflammatory process by activating mast cells and eosinophils (Spelberg and Junior, 2001; Cortés et al., 2017). Both subclasses of CD4 ${ }^{+}$cells are important and desired for host defense against different infectious pathogens.

The quantification of interleukins expressed by macrophages in vitro infected with $L$. braziliensis or $L$. infantum, showed that the peptide mix was capable of inducing a cytokine profile, which presented an increase in all the cytokines tested compared with the control group. Our data also revealed that the levels of IL-12, IFN- $\gamma$ and IL-4 mRNA expression by macrophages infected with L. braziliensis or L. infantum suggests the ability of these peptides to induce Th1 and Th2 polarization that can lead to a balanced response, no inflammatory pathologies, and protective immune response. According to the literature, the host immunity to a parasite is determined by a suitable Th1 response characterized by IL-12 and IFN- $\gamma$ production, and induction of iNOS in infected macrophages, which contributes to the control of parasite proliferation (Costa et al., 2002). Regarding the use of biomolecules as vaccine candidates, some studies reported an increase in the levels of IL-12 and IFN- $\gamma$ in animals immunized with ribosomal protein and infected with $L$. infantum and $L$. amazonensis (Chávez-Fumagalli et al., 2010). Martins et al. (2019) tested the immunogenicity of specific protein from Leishmania against $L$. major and L. braziliensis infection, and reported that the vaccination induced a Th1 response characterized by the production of IL-12 and IFN- $\gamma$.

Although immunity against Leishmania is well-known and defined as complex due to the mechanisms used by the parasite to survive in the host immune system. It is well-documented that Th1 response is responsible for inducing resistance to leishmaniosis through the production of inflammatory cytokines, such as IL-12 and IFN- $\gamma$, leading to the activation of macrophages and the killing of parasites. On the other hand, susceptibility to infection is related to Th2 development and IL-4 cytokine production, which leads to parasite resistance and replication (Chávez-Fumagalli et al., 2010).

The performance of immune response in immunopathology and the immunoprotection of leishmaniosis remain a paradox. For example, some studies report that, even though the Th1 response induces inflammatory cytokine production and plays a crucial role in the immunoprotection of leishmaniosis, their excessive production can lead to severe immunopathology in the disease (Sacks and Noben-Trauth, 2002; Martin and Leibovich, 2005; Nylén and Eidsmo, 2012). However, apart from inducing the persistence of the parasite at the site of injection, the Th2 response is able to induce anti-inflammatory cytokine production at lower levels, which can mitigate inflammatory reactions and accelerate the healing process (Nylén and Eidsmo, 2012; Pasparakis et al., 2014). These studies suggest that a balance between pro- and anti-inflammatory cytokines is essential, and desirable, to prevent immunopathological disorders and inflammatory reactions and can control the infection. This fact reinforces and corroborates our results that the peptide mix was able to induce the production of a cytokine profile that leads to a Th1 and Th2 immune response. In addition, the parasite load showed a reduction in the parasite. The next step of this study should be to evaluate the peptides in an in vivo model.

\section{CONCLUSIONS}

It was possible to encapsulate the peptides in the liposomes permitting the use of these molecules to entrap the peptides and delivering them for recognition as immunogenic epitopes by the immune mechanisms, while generating an appropriate immune response against these peptides. This indicates their ability to induce humoral immune response through the production of antibodies capable of reacting against $L$. braziliensis and $L$. 
infantum. They also demonstrate the ability to generate cellular immune response through the expression of cytokines that induce Th1 and Th2 polarization of $\mathrm{T}$ CD4+ cells, which leads to a balanced response, preventing immunopathological disorders and inflammatory reactions. Most of all, the peptides can lead to the expression of iNOS, the pivotal inductor of the effector molecule NO that controls parasite infection. Finally, these results suggest that the peptides can mimic the parasites proteins that present an important role in the hostparasite interaction, such as histones, and are targets to generate immunity against the parasites. In summary the mix of mimetic peptides tested in this work, by in vitro infection, demonstrated a satisfactory development for use as a potential candidate for leishmaniosis vaccines.

\section{DATA AVAILABILITY STATEMENT}

The original contributions presented in the study are included in the article/supplementary material, further inquiries can be directed to the corresponding author.

\section{ETHICS STATEMENT}

The animal study was reviewed and approved by Comissão de Ética no Uso de Animais Universidade Federal do Paraná.

\section{REFERENCES}

Abbas, A. K., Lichtman, A. H., and Pillai, S. (2015). Imunologia Celular e Molecular. 8th Edn. Amsterdam: Elsevier, 239-263.

Akbarzadeh, A., Rezaei-Sadabady, R., Davaran, S., Woo Joo, S., Zarghami, N., and Hanifehpour, Y. (2013). Liposome: classification, preparation, and applications. Nanoscale Res. Lett. 8:102. doi: 10.1186/1556-276X-8-102

Alavi, M., Karimi, N., and Safaei, M. (2017). Application of various types of liposomes in drug delivery systems. Adv. Pharm. Bull. 7, 3-9. doi: 10.15171/apb.2017.002

Alonso, C., and Soto, M. (2014). Development of anti-Leishmania vaccines: contribution of Spanish researchers. An. Real Acad. Farm. 80, 250-264. Available online at: https://core.ac.uk/download/pdf/230311897.pdf

Aslett, M., Aurrecoechea, C., Berriman, M., Brestelli, J., Brunk, B. P., and Carrington, M. (2010). TriTrypDB: a functional genomic resource for the Trypanosomatidae. Nucleic Acids Res. 38, 457-462. doi: 10.1093/nar/gkp851

Awate, S., Babiuk, L. A., and Mutwiri, G. (2013). Mechanisms of action of adjuvants. Front. Immunol. 4:114. doi: 10.3389/fimmu.2013.00114

Baharia, R. K., Tandon, R., Sahasrabuddhe, A. A., Sundar, S., and Dube, A. (2014). Nucleosomal histone proteins of $L$. donovani: a combination of recombinant $\mathrm{H} 2 \mathrm{~A}, \mathrm{H} 2 \mathrm{~B}, \mathrm{H}$, and $\mathrm{H} 4$ proteins were highly immunogenic and offered optimum prophylactic efficacy against Leishmania challenge in hamsters. PLoS ONE 9:e97911. doi: 10.1371/journal.pone.0097911

Beck, Z., Torres, B. O., Matyas, G. R., Lanar, D. E., and Alving, C. R. (2018). Immune response to antigen adsorbed to aluminum hydroxide particles: effects of co-adsorption of ALF or ALFQ adjuvant to the aluminum-antigen complex. J. Control Release 275, 12-19. doi: 10.1016/j.jconrel.2018.02.006

Bogdan, C. (2015). Nitric oxide synthase in innate and adaptive immunity: an update. Trends Immunol. 36, 161-178. doi: 10.1016/j.it.2015.01.003

Carneiro, M. W., Santos, D. M., Fukutani, K. F., Clarencio, J., Miranda, J. C., and Brodskyn, C. (2012). Vaccination with L. infantum chagasi nucleosomal histones confers protection against new world cutaneous

\section{AUTHOR CONTRIBUTIONS}

DG, MS, JC, and JCM performed the animal experiments. RM performed in silico analyses. VT-S, CS, JFM, and CC-O performed the conception and design of the work. VT-S and RM synthesized peptides. MS performed the assay qPCR for cytokines and parasites load. DG, VT-S, MS, GC, CS, and ER analyzed the data and wrote the draft of the manuscript. VT-S and CS corrected the final manuscript. VT-S supervised the entire project. All authors contributed to the article and approved the submitted version.

\section{FUNDING}

This study was funded by the Conselho Nacional de Desenvolvimento Científico e Tecnológico (CNPq; Grant Nos. 307387/2011-9 and 480292/2012-4), Fundação Araucária [Grant No. 122/2010 (Protocol 17401)], the Programa Nacional de Pós-Doutorado- Coordenação de Aperfeiçoamento de Pessoal de Nível Superior (PNPD-CAPES; Protocol 2847/2011), and scholarships granted to the two first authors.

\section{ACKNOWLEDGMENTS}

We thank the Centro de Produção e Pesquisa de Imunobiológicos (CPPI) of SESA, Paraná State, for technical support.

Leishmaniasis caused by Leishmania braziliensis. PLoS ONE 7:e52296. doi: 10.1371/journal.pone.0052296

Carrion, J., Folgueira, C., and Alonso, C. (2008). Transitory or long-lasting immunity to Leishmania major infection: the result of immunogenicity and multicomponent properties of histone DNA vaccines. Vaccine 26, 1155-1165. doi: 10.1016/j.vaccine.2007.12.051

Carrión, J., Folgueira, C., and Alonso, C. (2009). Development of Immunization Strategies against Leishmaniosis based on the Leishmania histones pathoantigens. Procedia Vaccinol. 1, 101-103. doi: 10.1016/j.provac.2009. 07.018

Chamakh-Ayari, R., Bras-Golçalves, R., Bahi-Jader, N., Petitdidier, E., MarkikouOuni, W., and Aoun, K. (2014). In vitro evaluation of a soluble Leishmania promastigote surface antigen as a potential vaccine candidate against human Leishmaniasis. PLoS ONE 9:e92708. doi: 10.1371/journal.pone.0092708

Chang, K. P., Reed, S. G., Mcgwire, B. S., and Soong, L. (2003). Leishmania model for microbial virulence: the relevance of parasite multiplication and pathoantigenicity. Acta Trop. 85, 375-390. doi: 10.1016/S0001-706X(02)00238-3

Chávez-Fumagalli, M. A., Costa, M. A., Oliveira, D. M., Ramirez, L., Costa, L. E., and Duarte, M. C. (2010). Vaccination with the Leishmania infantum ribosomal protein induces protection in BALB/c mice against Leishmania chagasi and Leishmania amazonensis challenge. Microbes Infect. 12, 967-977. doi: 10.1016/j.micinf.2010.06.008

Cortés, A., Muñoz-Antoli, C., Esteban, J. G., and Toledo, R. (2017). Th2 and Th1 responses: clear and hidden sides of immunity against intestinal helminths. Trends Parasitol. 33, 679-693. doi: 10.1016/j.pt.2017.05.004

Costa, C. H., Stewart, J. M., Gomes, R. B., Garcez, L. M., Ramos, P. K., and Bozza, M. (2002). Assymptomatic human carriers of Leishmania chagasi. Am. J. Trop. Med. Hyg. 66, 334-337. doi: 10.4269/ajtmh.2002.66.334

De Brito, R. C. F., De O Cardoso, J. M., Reis, L. E. S., Vieira, J. F., Mathias, F. A. S., Roatt, B. M., et al. (2018). Peptide vaccines for Leishmaniasis. Front. Immunol. 9:1043. doi: 10.3389/fimmu.2018.01043 
Frank, R. (2002). The spot-synthesis technique. Synthetic peptide arrays on membrane supports-principles and applications. J. Immunol. Methods 267, 13-26. doi: 10.1016/S0022-1759(02)00137-0

Freitas, E., Silva, R., Ferreira, L. F., Hernandes, M. Z., De Brito, M. E., and De Oliveira, B. C. (2016). Combination of in silico methods in the search for potential CD4(+) and CD8(+) T cell epitopes in the proteome of Leishmania braziliensis. Front. Immunol. 7:327. doi: 10.3389/fimmu.2016.00327

Guedes, D. C., Pasquali, A. K. S., Minozzo, J. C., Faulds, C., Petterle, R. R., Soccol, C. R., et al. (2019). Biological evaluation of mimetic peptides as active molecules for a new and simple skin test in an animal model. Parasitol. Res. 118, 317-324. doi: 10.1007/s00436-018-6128-8

Guex, N., and Peitsch, M. C. (1997). SWISS-MODEL and the Swiss-PdbViewer: an environment for comparative protein modeling. Electrophoresis 18, 2714-2723. doi: 10.1002/elps.1150181505

Hamrouni, S., Bras-Gonçalves, R., Kidar, A., Aoun, K., Chamakh-Ayari, R., Petitdidier, E., et al. (2020). Design of multi-epitope peptides containing HLA class-I and class-II-restricted epitopes derived from immunogenic Leishmania proteins, and evaluation of CD4+ and CD8 $+\mathrm{T}$ cell responses induced in cured cutaneous leishmaniasis subjects. PLoS Negl. Trop. Dis. 14:e0008093. doi: 10.1371/journal.pntd.0008093

Handman, E. (2001). Leishmaniasis: current status of vaccine development. Clin. Microbiol. Rev. 14, 229-243. doi: 10.1128/CMR.14.2.229-243.2001

$\mathrm{He}, \mathrm{P} ., \mathrm{Zou}, \mathrm{Y}$., and $\mathrm{Hu}, \mathrm{Z}$. (2015). Advances in aluminum hydroxide-based adjuvant research and its mechanism. Hum. Vaccin. Immunother. 11, 477-488. doi: 10.1080/21645515.2014.1004026

Herrera-Najera, C., Pina-Aguilar, R., Xacur-Garcia, F., Ramirez-Sierra, M. J., and Dumonteil, E. (2009). Mining the Leishmania genome for novel antigens and vaccine candidates. Proteomics 9, 1293-1301. doi: 10.1002/pmic.200800533

Iborra, S., Soto, M., Carrion, J., Alonso, C., and Requena, J. M. (2004). Vaccination with a plasmid DNA cocktail encoding the nucleosomal histones of Leishmania confers protection against murine cutaneous leishmaniosis. Vaccine 22, 3865-3876. doi: 10.1016/j.vaccine.2004.04.015

Joshi, S., Rawat, K., Yadav, N. K., Kumar, V., Siddiqi, M. I., and Dube, A. (2014). Visceral leish-maniasis: advancements in vaccine development via classical and molecular approaches. Front. Immunol. 5:380. doi: 10.3389/fimmu.2014.00380

Khamesipour, A., Rafati, S., Davoudi, N., Maboudi, F., and Modabber, F. (2006). Leishmaniasis vaccine candidates for development: a global overview. Indian J. Med. Res. 123, 423-438.

Kozlowski, L. P. (2016). IPC-isoelectric point calculator. Biol. Direct 11:55. doi: 10.1186/s13062-016-0159-9

Lakhal, S., Mekki, S., Ben-Abda, I., Mousli, M., Amri, F., and Aoun, K. (2012). Evaluation of an Enzyme-linked immunosorbent assay based on crude Leishmania histone proteins for serodiagnosis of human infantile visceral Leishmaniasis. Clin. Vaccine Immunol. 19, 1487-1491. doi: 10.1128/CVI.00257-12

Link, J. S., Alban, S. M., Soccol, C. R., Pereira, G. V. M., and ThomazSoccol, V. (2017). Synthetic peptides as potential antigens for cutaneous leishmaniosis diagnosis. J. Immunol. Res. 2017:5871043. doi: 10.1155/2017/58 71043

Livak, K. J., and Schmittgen, T. D. (2001). Analysis of relative gene expression data using real-time quantitative PCR and the $2^{-\Delta \Delta \mathrm{cT}}$ Method. Methods 25, 402-408. doi: 10.1006/meth.2001.1262

Maroof, A., Brown, N., Smith, B., Hodgkinson, M. R., Maxwell, A., and Losch, F. O. (2012). Therapeutic vaccination with recombinant adenovirus reduces splenic parasite burden in experimental visceral leishmaniasis. J. Infect. Dis. 205, 853-863. doi: 10.1093/infdis/jir842

Martin, P., and Leibovich, S. J. (2005). Inflammatory cells during wound repair: the good, the bad, and the ugly. Trends Cell Biol. 15, 599-607. doi: $10.1016 /$ j.tcb.2005.09.002

Martínez Salazar, M. B., Delgado Domínguez, J., Silva Estrada, J., González, C. B., and Becker, I. (2014). Vaccination with Leishmania mexicana LPG induces 81 PD-1 in CD8+ and PD-L2 in macrophages thereby suppressing the immune response: a model to assess vaccine efficacy. Vaccine 32, 1259-1265. doi: 10.1016/j.vaccine.2014.01.016

Martins, T., Lage, D. P., Duarte, M. C., Costa, L. E., Chavez-Fumagalli, M. A., and Roatt, B. M. (2019). Cross-protective efficacy from an immunogen firstly identified in Leishmania infantum against tegumentary leishmaniasis. Parasite Immunol. 38, 108-117. doi: 10.1111/pim.12304
Meddeb-Garnaoui, A., Toumi, A., Ghelis, H., Mahjoub, M., Louzir, H., and Chenik, M. (2010). Cellular and humoral responses induced by Leishmania histone $\mathrm{H} 2 \mathrm{~B}$ and its divergent and conserved parts in cutaneous and visceral Leishmaniasis patients, respectively. Vaccine 28, 1881-1886. doi: 10.1016/j.vaccine.2009.11.075

Melo, P. D. V., Lima, S. A., Araujo, P., Santos, T. M., Gonzalez, E., Belo, A. A., et al. (2020). Immunoprotection against lethal effects of Crotalus durissus snake venom elicited by synthetic epitopes trapped in liposomes. Int. J. Biol. Macromol. 161, 299-307. doi: 10.1016/j.ijbiomac.2020.05.171

Merrifield, R. (1969). Solid-phase peptide synthesis. Adv. Enzymol. Relat. Areas Mol. Biol. 32, 221-296. doi: 10.1002/9780470122778.ch6

Moyle, P. M., and Toth, I. (2013). Modern subunit vaccines: development, components, and research opportunities. ChemMedChem 8, 360-376. doi: $10.1002 / \mathrm{cmdc} .201200487$

Mukherjee, S., Zhu, J., Zikherman, J., Parameswaran, R., Kadlecek, T. A., and Wang, Q. (2013). Monovalent and multivalent ligation of the B cell receptor exhibit differential dependence upon syk and src family kinases. Sci. Signal. 6:ral. doi: 10.1126/scisignal.2003220

Mutiso, J. M., Macharia, J. C., and Gicheru, M. M. (2010). A review of adjuvants for Leishmania vaccine candidates. J. Biomed. Res. 24, 16-25. doi: 10.1016/S1674-8301(10)60004-8

Nylén, S., and Eidsmo, L. (2012). Tissue damage and immunity in cutaneous leishmaniasis. Parasite Immunol. 34, 551-561. doi: 10.1111/pim.12007

Oh, S. A., and Li, M. O. (2013). TGF- $\beta 3$ : guardian of t-cell function. J. Immunol. 191, 3973-3979. doi: 10.4049/jimmunol.1301843

Okamura, T., Morita, K., Iwasaki, Y., Inoue, M., Komai, T., Fujio, K., et al. (2015). Role of TGF- $\beta 3$ in the regulation of immune responses. Clin. Exp. Rheumatol. 34, 63-69.

Olivier, M., Atayde, D., Isnard, A., Hassani, K., and Shio, M. (2012). T. Leishmania virulence factors: focus on the metalloprotease GP63. Microbes Infect. 14, 1377-1389. doi: 10.1016/j.micinf.2012.05.014

Pasparakis, M., Haasen, I., and Nestle, F. O. (2014). Mechanisms regulating skin immunity and inflammation. Nat. Rev. Immunol. 15, 289-301. doi: $10.1038 /$ nri3646

Passos, S., Carvalho, L. P., Orge, G., Jeronimo, S. M., Bezerra, G., and Soto, M. (2005). Recombinant Leishmania antigens for serodiagnosis of visceral Leishmaniasis. Clin. Diagn. Lab. Immunol. 12, 1164-1167. doi: 10.1128/CDLI.12.10.1164-1167.2005

Pini, A., Giuliani, A., Falciani, C., Runci, Y., Ricci, C., and Lelli, B. (2005). Antimicrobial activity of novel dendrimeric peptides obtained by phage display selection and rational modification. Antimicrob. Agents Chemother. 49, 2665-2672. doi: 10.1128/AAC.49.7.2665-2672.2005

Requena, J. M., Alonso, C., and Soto, M. (2000). Evolutionarily conserved proteins as prominent immunogens during Leishmania infections. Parasitol. Today 16, 246-250. doi: 10.1016/S0169-4758(00)01651-3

Rhaiem, R. B., and Houimel, M. (2016). Targeting Leishmania major parasite with peptides derived from a combinatorial phage display library. Acta Trop. 159, 11-19. doi: 10.1016/j.actatropica.2016.03.018

Rice, P., Longden, I., and Bleasby, A. (2000). EMBOSS: The European Molecular Biology Open Software Suite. Trends Genet. 16, 276-277. doi: 10.1016/S0168-9525(00)02024-2

Rubinstein, N. D., Mayrose, I., Martz, E., and Pupko, T. (2009). Epitopia: a web-server for predicting B-cell epitopes. BMC Bioinformatics 10:287. doi: 10.1186/1471-2105-10-287

Sacks, D., and Noben-Trauth, N. (2002). The immunology of susceptibility and resistance to Leishmania major in mice. Nat. Rev. Immunol. 2, 845-858. doi: 10.1038/nri933

Saha, S., and Raghava, G. P. S. (2006). Prediction of continuous B-cell epitopes in an antigen using recurrent neural network. Proteins 65, 40-48. doi: $10.1002 /$ prot. 21078

Santarem, N., Silvestre, R., Tavares, J., Silva, M., Cabral, S., Maciel, J., et al. (2007). Immune response regulation by Leishmania secreted and nonsecreted antigens. J. Biomed. Biotechnol. 2007:85154. doi: 10.1155/2007/85154

Seger, J. (2014). Peptídeos sintéticos para diagnóstico e imunoprofilaxia da leishmaniose tegumentar americana (Dissertation). Federal University of Parana, Curitiba, Brazil.

Singh, B., and Sundar, S. (2012). Leishmaniasis: vaccine candidates and perspectives. Vaccine 30, 3834-3842. doi: 10.1016/j.vaccine.2012.03.068 
Skwarczynski, M., and Toth, I. (2016). Peptide-based synthetic vaccines. Chem. Sci. 7, 842-854. doi: 10.1039/C5SC03892H

Soto, M., Requena, J. M., Gomez, L. C., Navarrete, I., and Alonso, C. (1992). Molecular characterization of a Leishmania donovani infantum antigen identified as histone H2A. Eur. J. Biochem. 205, 211-216. doi: 10.1111/j.1432-1033.1992.tb16770.x

Soto, M., Requena, J. M., Morales, G., and Alonso, C. (1994). The Leishmania infantum histone $\mathrm{H} 3$ possesses an extremely divergent $\mathrm{N}$ terminal domain. Biochim. Biophys. Acta 1219, 533-535. doi: 10.1016/0167-4781(94)90082-5

Soto, M., Requena, L. M., Quijana, L., Perez, M. L., Nieto, C. G., and Guzman, F. (1999). Antigenicity of the Leishmania infantum histones H2B and H4 during canine viscerocutaneous Leishmaniasis. Clin. Exp. Immunol. 115, 342-349. doi: 10.1046/j.1365-2249.1999.00796.x

Souza, A. P., Soto, M., Costa, J. M., Boaventura, S., De Oliveira, C. I., and Cristal, J. R. (2013). Towards a more precise serological diagnosis of human tegumentary Leishmaniasis using Leishmania recombinant proteins. PLoS ONE 8:e66110. doi: 10.1371/journal.pone.0066110

Spelberg, B., and Junior, J. E. E. (2001). Type 1/Type 2 immunity in infectious diseases. Clin. Infect. Dis. 32, 76-102. doi: 10.1086/317537

Thomaz-Soccol, V., Alban, S., and Seger, J. (2015). Peptídeos miméticos de Leishmania sp. Processo para sua obtenção e aplicações. Patent.

Thomaz-Soccol, V., Ferreira Da Costa, E. S., Karp, S. G., Junior Letti, L. A., Soccol, F. T., and Soccol, C. R. (2018). Recent advances in vaccines against
Leishmania based on patent applications. Recent Pat. Biotechnol. 12, 21-32. doi: $10.2174 / 1872208311666170510121126$

Toledo-Machado, C. M., Bueno, L. L., Menezes-Souza, D., Machado-De-Avila, R. A., Nguyen, C., and Granier, C. (2015). Use of phage display technology in development of canine visceral Leishmaniasis vaccine using synthetic peptide trapped in sphingomyelin/ cholesterol liposomes. Parasit. Vectors 8:133. doi: 10.1186/s13071-015-0747-z

Vita, R., Overton, J. A., Greenbaum, J. A., Ponomarenko, J., Clark, J. D., and Cantrell, J. R. (2015). The immune epitope database (IEDB) 3.0. Nucleic Acids Res. 43, 405-412. doi: 10.1093/nar/gku938

Conflict of Interest: The authors declare that the research was conducted in the absence of any commercial or financial relationships that could be construed as a potential conflict of interest.

Copyright (๑) 2021 Guedes, Santiani, Carvalho, Soccol, Minozzo, Machado de Ávila, de Moura, Ramos, Castro, Chávez-Olórtegi and Thomaz-Soccol. This is an openaccess article distributed under the terms of the Creative Commons Attribution License (CC BY). The use, distribution or reproduction in other forums is permitted, provided the original author(s) and the copyright owner(s) are credited and that the original publication in this journal is cited, in accordance with accepted academic practice. No use, distribution or reproduction is permitted which does not comply with these terms. 